https://doi.org/10.11646/zootaxa.4559.2.4

http://zoobank.org/urn:lsid:zoobank.org:pub:A6DEC6FF-25E2-4D57-A88C-28E0CEF603DC

\title{
The ichthyology collection at the Natural History Museum of EI Salvador (MUHNES): Species checklist and new country records
}

\author{
SAÚL GONZÁLEZ-MURCIA ${ }^{1,2,3}$, FRANCISCO SAMUEL ÁLVAREZ-CALDERÓN ${ }^{1,2,4}$, \\ RAQUEL ALVARADO-LARIOS ${ }^{5, *}$, CINDY MARLENE MARÍN-MARTÍNEZ ${ }^{1,2}$ \& ARTURO ANGULO ${ }^{6,7}$ \\ ${ }^{1}$ UDP Ciencias Neotropicales, Pasaje Francisco Campos \#166, Colonia Escalón, San Salvador. \\ E-mail: udpcienciasneotropicales@gmail.com (FAC) \\ ${ }^{2}$ Fundación Naturaleza El Salvador, Pasaje Francisco Campos \#166, Colonia Escalón, San Salvador. \\ E-mail: fundanaturaleza@gmail.com;cindy.3m@gmail.com (CMM) \\ ${ }^{3}$ School of Marine and Tropical Biology, James Cook University, Queensland, 4811, Australia. \\ E-mail: saul.gonzalezmurcia@my.jcu.edu.au (SGM) \\ ${ }^{4}$ Centro Agronómico Tropical de Investigación y Enseñanza (CATIE), Costa Rica \\ ${ }^{5}$ Museo de Historia Natural de El Salvador, Barrio San Jacinto, final calle Los Viveros, colonia Nicaragua, San Salvador. E-mail: \\ rcalvarado@cultura.gob.sv; raquel9.al@gmail.com(RAL) \\ ${ }^{6}$ Museo de Zoología y Centro de Investigación en Ciencias del Mar y Limnología (CIMAR), Universidad de Costa Rica. 11501-2060, \\ San Pedro de Montes de Oca, San José, Costa Rica.E-mail: arturo.angs@gmail.com (AA) \\ ${ }^{7}$ UNESP, Universidade Estadual Paulista “Júlio de Mesquita Filho", Laboratório de Ictiologia, Departamento de Zoologia e Botâni- \\ ca. Rua Cristóvão Colombo, 2265, CEP 15054-000, São José do Rio Preto, SP, Brazil \\ *Corresponding author
}

\begin{abstract}
The ichthyology collection at the Natural History Museum of El Salvador (MUHNES) was established in 1970. Herein, we provide the first quantitative and qualitative description of the collection; and the first public record of the specimens and taxa therein represented. The MUHNES fish collection is the largest and most important of El Salvador, hosting 3791 specimens in 1005 lots representing 26 orders, 75 families, 159 genera and 248 species from both marine and freshwater environments, including larval, juvenile and mainly adult specimens. MUHNES specimens include $39 \%$ of the 587 species reported in the official national checklist of fishes of El Salvador, and support the inclusion of 47 additional species for a new total of 634. Furthermore, MUHNES specimens support (1) the occurrence of Cathorops fuerthii along the coast of El Salvador, extending its distribution from northern Costa Rica; (2) the occurrence of Atherinella starksi in El Salvador, reducing a gap for records between Nicaragua and México and (3) the extension in the distribution range of Profundulus kreiseri to Morazán, El Salvador. This study represents an advance on the understanding of diversity and distribution of the national ichthyofauna.
\end{abstract}

Key words: Neotropical Fishes, Eastern Tropical Pacific, Central America, Fish Collection, Diversity, Taxonomy, Biogeography

\section{Resumen}

La colección ictiológica del Museo de Historia Natural de El Salvador (MUHNES) fue establecida en 1970. Aquí se presenta la primera descripción cuantitativa y cualitativa de la colección de peces en el MUHNES. La colección del MUHNES es la más grande e importante de El Salvador, albergando 3,791 especímenes en 1,005 lotes, los cuales representan 26 órdenes, 75 familias, 159 géneros y 248 especies, provenientes de ambientes marinos y dulceacuícolas, incluyendo estadios larvales, juveniles y, principalmente, adultos. Los especímenes del MUHNES incluyen cerca del $39 \%$ de las 587 especies de peces reportadas en el listado nacional oficial para El Salvador, respaldando, además, la inclusión de 47 especies adicionales, generando un nuevo total de 634 especies para El Salvador. Además, especímenes de la colección apoyan (1) la presencia de Cathorops fuerthii en la costa de El Salvador extendiendo su distribución desde el Norte de Costa Rica; (2) la presencia de Atherinella starksi en El Salvador, reduciendo la ausencia de registros entre Nicaragua y México y (3) 
la extensión en el ámbito de distribución de Profundulus kreiseri hasta Morazán, El Salvador. Este estudio representa un avance para el entendimiento de la diversidad y distribución de la ictiofauna nacional.

Palabras clave: Peces Neotropicales, Pacífico Oriental Tropical, Centroamérica, Colección de Peces, Diversidad, Taxonomía, Biogeografía

\section{Introduction}

Natural history collections around the world play a key role in advancing the understanding of the diversity of life. The biological material contained in collections allow us (1) to have basic knowledge on species diversity and distribution patterns; (2) to answer questions on phylogenetic systematics; (3) to understand changes in distribution at different temporal and spatial scales, for example due to habitat loss; and (4) to understand patterns of introduction of invasive species, as well as the effects of climate change on species diversity and distribution, among others (see Shaffer et al. 1998; Sala et al. 2000; Ponder et al. 2001; Vörösmarty et al. 2003; Thiel et al. 2009; Vörösmarty et al. 2010; Hammer 2012). Furthermore, the biological specimens or material (e.g. skeletons, tissues, otoliths and DNA sequences), are usually the starting point that triggers top-of-the-line research in multiple scientific fields (Barber et al. 1972; Hammer 2012). In some cases, the outcomes of this research have produced results that are of significant interest for public health and safety, agriculture, and the conservation of species and ecosystems; or have allayed some misconceptions and fears in society (Suarez \& Tsutsui 2004).

Benefits generated by natural history collections far exceed the cost incurred in their maintenance (Suarez \& Tsutsui 2004), since collections are data sources that support the dissemination of information among the scientific community and the general public. Thus, collections can help to identify locations where a species of interest might be present, or facilitate access to specimens from remote locations that can be hard to sample due to distance, political reasons and lack of financial resources (Suarez \& Tsutsui 2004). Moreover, natural history collections can reduce the redundancy and duplication of collection efforts, whereas the associated online databases can diminish costs for many research purposes by giving access to basic information that can be readily employed in scientific publications. Indeed, many museums and collections loan specimens to researchers and exchange specimens with other institutions. Despite their valuable contribution to society and our broader understanding of global biodiversity, natural science collections have experienced a decline in funding in recent years (Dalton 2003). As in many Latin American countries, in El Salvador, funding has been redirected to solve problems relating to public health and agriculture (Horta-Duarte 2013), neglecting the importance of natural scientific collections.

Founded on 9 October 1883, the Natural History Museum of El Salvador (Museo de Historia Natural de El Salvador, MUHNES,) is a governmental institution that started as the house of multiple scientific collections including sections for natural resources, art objects, antiquities and geology. The MUHNES was relocated many times between 1883 and 1926; initially it was situated in the building of the University of El Salvador, in the city center of San Salvador, then it was relocated to: the National Library, the House "Villa España", the "Finca Modelo" and the Faculty of Pharmacy and Chemistry of the University of El Salvador. From 1927 to 1962 the MUHNES was placed next to the Presidential House, and in 1941 it was rearranged in two sections, the department of anthropology and the department of natural sciences (Echeverría 2013). In 1974 the department of anthropology became the National Museum of Anthropology "Dr. David J. Guzmán”. In 1976 Mr. Saburo Hirao (CEO of the Japanese company Toyobo Co. LTD) provided financial support for the establishment of the Park Saburo Hirao, in San Jacinto, department of San Salvador. The main building in the park was assigned to the department of natural sciences and to house collections of vertebrates, fossils, minerals, rocks and plants.

The ichthyology collection of the MUHNES was formally established in 1970, but it was not until 1976 that the collection started to mature with the combined support of the first director of the museum, Mr. Víctor Hellebuyck, and the cooperation of researchers from the Service of National Parks and Wild Life of El Salvador (Servicio de Parques Nacionales y Vida Silvestre, PANAVIS) and the United States Peace Corps (Echeverría 2013). But the collection also suffered important losses of material after strong earthquakes in 1986 and 2001, with the latest event affecting almost $60 \%$ of the specimens when many glass jars containing specimens broke (Echeverría per. com. 30 March 2017). As a result, the registry book was rewritten and the collection was reorganized (Echeverría 2013). Since then, the goal of the MUHNES's ichthyology collection has been to increase its geographical and taxonomic scope with the support of national and international ichthyologists. 
The information in the records of the MUHNES's ichthyology collection is considered an important research resource for understanding the biodiversity of fishes in El Salvador, particularly because in the last decade numerous efforts have increased the number of species in the country based on voucher specimens deposited at the collection (See Rojas et al. 2006; González-Murcia \& Marín-Martínez 2011; González-Murcia et al. 2012; Álvarez et al. 2013; McMahan et al. 2013; González-Murcia et al. 2016). Nonetheless, until now a comprehensive assessment of the status of the MUHNES's ichthyology collection has not been carried out, nor has there been an updated digital format for the catalog book (registry), which limits access to its material. Therefore, this study pursued the following objectives: (1) to generate the first officially published records of the ichthyology collection of the MUHNES; (2) to characterize quantitatively and qualitatively the ichthyology collection; and (3) to update the metadata associated to the specimens in the collection catalog. To the knowledge of the authors, this is the first effort of this type conducted in the MUHNES, and, with this, we expect it to support research initiatives on fishes of El Salvador in the near future.

\section{Material and methods}

Since its establishment, the MUHNES ichthyology collection data was manually recorded in the registry book. For each taxonomic lot (rows) the book contains the following information (columns): a unique and continuous catalog number, with the number 40 as prefix code identifying the ichthyology collection; classification (i.e., order, family, genus and species); number of specimens; identification date; and collection data including locality, geographic coordinates, collection date, name of the collector, elevation and collection method. The collection localities and ecosystem types were categorized as freshwater (F; lakes or rivers), brackish waters (B; estuaries with variables levels of salinity) or marine (M; coastal areas or open waters, with salinities of 33 to $35 \mathrm{mg} / \mathrm{l})$. Inland species were categorized by salinity tolerance as primary (Pr), secondary (Se) or peripheral (Pe), following Myers (1949) and previous species occurrence records by McMahan et al. (2013). Additionally the ontogenetic stage of the specimens as larvae (L), juvenile (J) or adult (A) was determined using anatomical and morphological traits, coloration patterns and total length.

The size of the collection (688 cataloged taxonomic lots, previous to this revision) allowed us to implement an intensive examination of each lot, followed by a meticulous taxonomic identification and verification based on the original descriptions and keys available: Fisher et al. (1995), Bussing (2002), Miller et al. (2009) and Robertson \& Allen (2015). Uncataloged material also was examined, identified and incorporated into the collection. The resulting species list follows the systematic arrangement proposed by Nelson et al. (2016); species valid names, their authority(ies), and year of publication are provided according to Eschmeyer et al. (2018). Distribution ranges were contrasted with the ones reported in the literature (mainly McMahan et al. 2013 and Robertson \& Allen 2015), as well as the Catalog of Fishes Online Database (Eschmeyer et al. 2018) and FishBase (Froese \& Pauly 2017).

A description of the progress of the MUHNES ichthyology collection, in relation to the growth of its acquis and its taxonomic scope, since its establishment in 1970 was done using the catalog information; and a comparison between the list "Inventory of the Fishes from El Salvador" (MARN 2016) from the Ministry of Environment and Natural Resources of El Salvador (Ministerio de Medio Ambiente y Recursos Naturales, MARN), and those species cataloged and vouchered in the ichthyology collection of the MUHNES was performed.

In addition to the revision of the material, the following curatorial work was done on the collection: ethanol (70\%) was replaced when necessary; labels, when appropriate were added to each lot, with the taxonomic and collection information (species name, collector, person who identified the specimen, date of identification, location, geographic coordinates and collection date); taxon names were updated and spelling mistakes corrected. Finally, an electronic updated database (Excel file) of the material hosted in the collection was produced, which can be accessed by request to the MUHNES staff. 


\section{Results}

\section{Development of MUHNES fish collection}

Following our revision completed on December 2017, the MUHNES collection is composed of 3791 specimens in 1005 lots. This represents an increase of 46\% (317 lots) compared to the number previously cataloged (688 lots accessioned between 1974 and April 2017) (Fig 1). The oldest cataloged lot dates from 1974 (MUHNES 40-198), contains two specimens of the Panamic Frillfin Bathygobius ramosus Ginsburg 1947, collected by L. Nylor in La Barra de Santiago, Ahuachapán. Overall, relevant contributions to the ichthyology collection were made by L. Nylor (1974-1980), P. Phillips (1976), E. León and S. Andino (1977-1989), J.J. Orellana (1983-1989), E. Barraza and M. Vázquez (1989-2017), R. Robertson and C. Baldwin, (2001), M. Méndez (2006), C. Marín (2009-2011), S. González-Murcia (2009-2017) and F. Álvarez (2011-2017). The specimens deposited by those researchers represent $85 \%$ of the specimens held in the collection (Fig. 1).

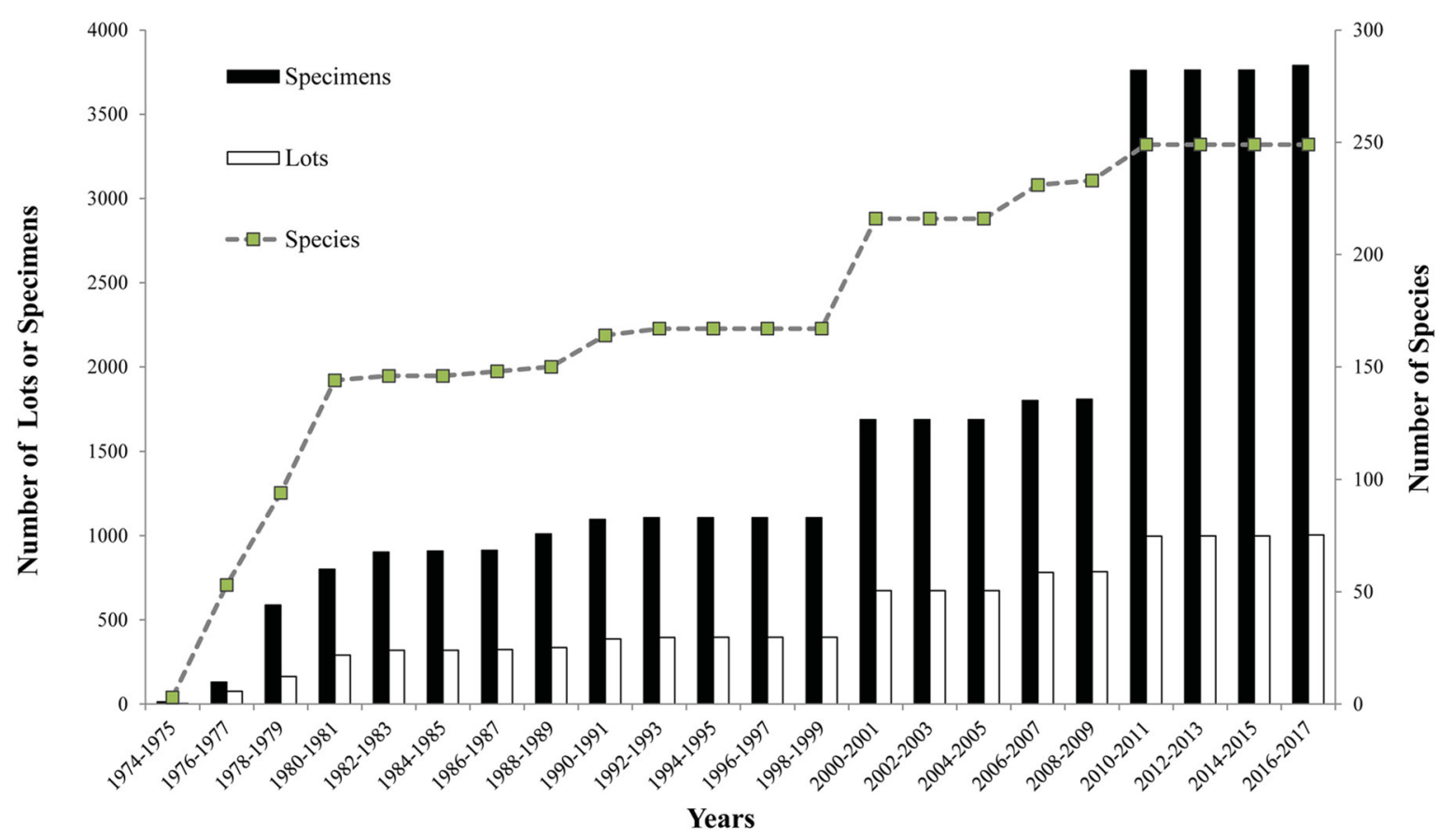

FIGURE 1. Cumulative number of accessioned specimens, lots and species from 1974 to 2017 by 2-year periods, at the MUHNES ichthyology collection.

During the period 1974-2017 the MUHNES acquisition of specimens was not constant (Fig. 1). Some periods showed remarkable increments in the number of specimens added to the collection, these include 1978-1979, 2000-2001 and 2010-2011, with a contribution of 12\%, 15\% and 52\% respectively. These events represent research campaigns conducted by L. Nylor (1974-1980) along the coast of the departments of Ahuachapán, Sonsonate, La Libertad, La Paz and La Unión; the collections of R. Robertson and C. Baldwin (2001) during their exploration of the El Salvador coast $(321 \mathrm{~km})$ on the Research Vessel Urraca from the Smithsonian Institution; and multiple research initiatives in 2010-2011 that provided specimens from Sonsonate, La Libertad, San Vicente and La Unión. During the last period, important specimens were added to the collection, such as the first specimens of larval stages of fishes from marine origin collected by Marín-Martínez (2011), the first El Salvador records of the clingfish Tomicodon zebra (Jordan \& Gilbert 1882) (González-Murcia \& Marín-Martínez 2011), and the livebearer Pseudoxiphophorus anzuetoi (Rosen \& Bailey 1979) (Álvarez et al. 2013). Also, many freshwater specimens were added from an intensive collection campaign in several watersheds of El Salvador, which provided a better understanding of the distribution of the inland fishes of the country.

Regardless the relative short time of existence of the MUHNES ichthyology collection (about 4 decades), it has a strong historical and scientific significance by (1) holding specimens that represent relatively well the 
biodiversity of fishes in El Salvador; (2) contributing towards the scientific development of the country by allowing researchers access to the specimens; and (3) supporting scientific records published in peer review papers. As previously mentioned, currently there is a digital copy of the catalog information that is expected to be the starting point to launch the information of the ichthyology collection on a digital open-access portal in the near future. To date, the collection continues to expand, with new material arriving and waiting to be processed and cataloged.

\section{Geographic and taxonomic scope of the MUHNES fish collection}

The MUHNES ichthyology collection is composed of 3791 specimens representing 26 orders, 75 families, 159 genera, and 248 species, plus 28 lots that remain without species-level identifications (Table 1). The most recent and complete inventory of the fish species occurring in El Salvador reported a total of 139 families and 587 species (MARN 2016). This revision supports the addition of 47 species, reaching 634 species. From these 634 species recorded in El Salvadorian waters, 248 (39\%) have voucher specimens in the MUHNES ichthyology collection (Table 1).

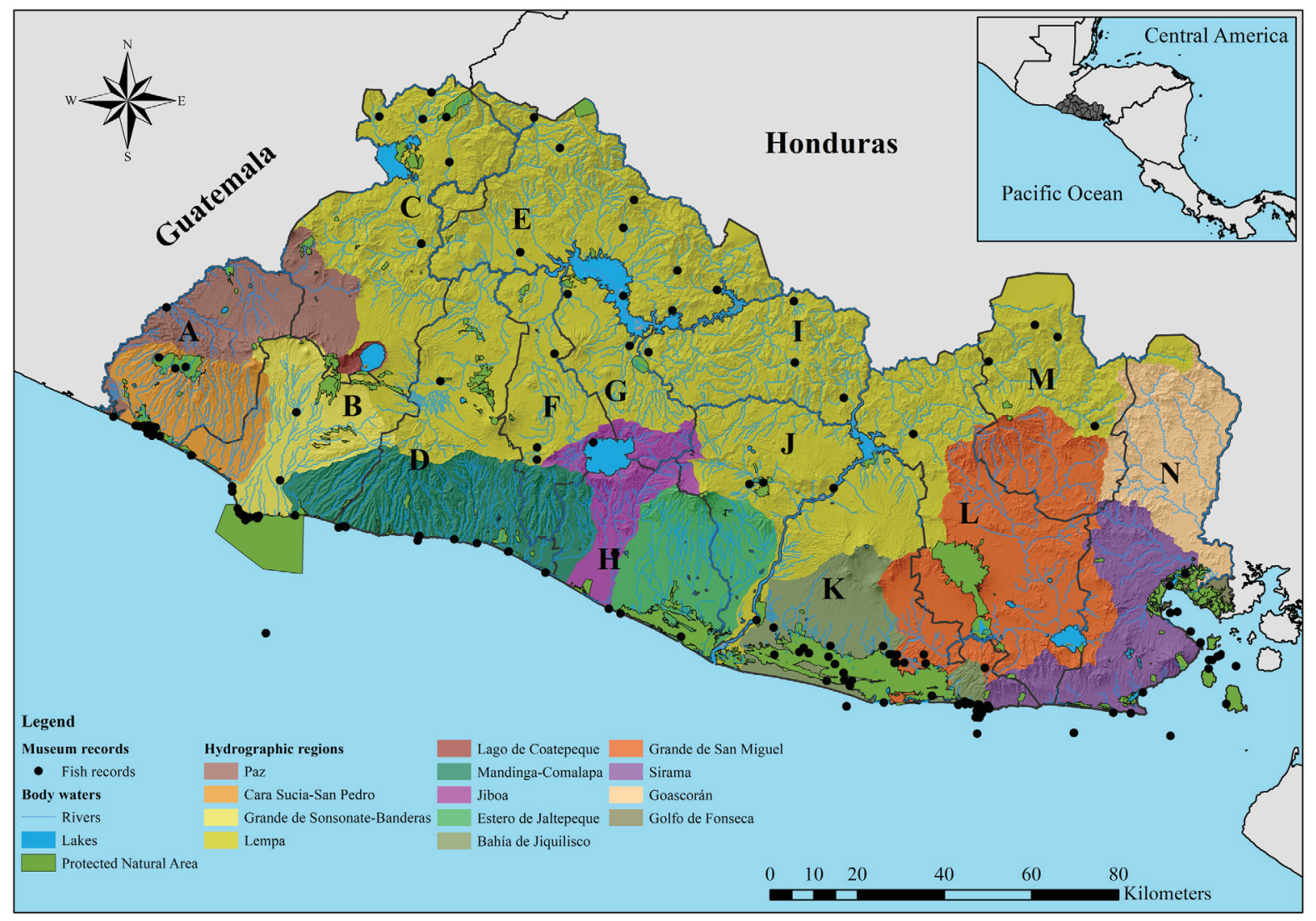

FIGURE 2. Collection localities represented at the MUHNES Ichthyology collection. Inland aquatic ecosystems, divided by hydrogeographic regions, marine environments, protected areas and the political division of El Salvador are illustrated. $\mathrm{A}=$ Ahuachapán, B = Sonsonate, $\mathrm{C}=$ Santa Ana, $\mathrm{D}=$ La Libertad, $\mathrm{E}=$ Chalatenango, $\mathrm{F}=$ San Salvador, $\mathrm{G}=\mathrm{Cuscatlán,} \mathrm{H}=\mathrm{La}$ Paz, $\mathrm{I}=$ Cabañas, $\mathrm{J}=$ San Vicente, $\mathrm{K}=$ Usulután, $\mathrm{L}=$ San Miguel, $\mathrm{M}=$ Morazán N = La Unión.

The MUHNES collection is focused on local fish fauna and there are specimens from multiple regions, watersheds and ecosystems in El Salvador (Fig. 2). Biogeographically, all freshwater specimens and species hosted by the collection belong to the Chiapas-Nacaome area, within the Nuclear Middle America region (Matamoros et al. 2012a; Matamoros et al. 2015), previously considered the Chiapas-Fonseca province of the Central America region by Abell et al. (2008). Marine specimens belong to the Panamic zoogeographic province, which spans from 
Mazatlán bay, approximately $\sim 23^{\circ} \mathrm{N}$, to the Gulf of Guayaquil, Ecuador-Peru, approximately $\sim 4^{\circ} \mathrm{S}$, within the Tropical Eastern Pacific (TEP) (Robertson \& Cramer 2009). Currently, the collection does not host material from other biogeographical areas within the TEP, nor other parts of the world.

A total of 210 lots (21\%) belong to freshwater environments, whereas $291(29 \%)$ and $504(50 \%)$ belong to brackish and marine ecosystems, respectively (Table 1). Most species were collected exclusively in one environment, marine $(170,61 \%)$, brackish $(16,6 \%)$ or freshwater $(27,10 \%)$, while few species were collected in two or three different environments: marine/brackish $(49,17 \%)$, brackish/freshwater $(9,3 \%)$ and marine/brackish/ freshwater environments $(9,3 \%)$ (Table 1). Based on the categorization of Myers (1949) and previous records presented by McMahan et al. (2013), Alda et al. (2013), Palacios et al. (2016) and Álvarez et al. (2017) for inland fishes of El Salvador, there are four primary freshwater species (3\%), 24 secondary species (23\%) and 73 peripheral species (73\%). All the primary species, $87 \%$ (21/24) of the secondary species [excluding Amatitlania coatepeque Schmitter-Soto 2007, synonymized with A. nigrofasciata (Günther 1867) by McMahan et al. (2014); Poecilia butleri Jordan 1889 and P. gillii (Kner 1863) reported by McMahan et al. (2013), because molecular evidence suggest that these species do not occur in El Salvador (Alda et al. 2013; Palacios et al. 2016)] and 68\% (50/73) of the peripheral species reported by McMahan et al. (2013) have voucher specimens deposited at the MUHNES collection. In addition, 23 new records of peripheral species were added to the list of McMahan et al. (2013), increasing the number of peripheral fishes to 96 and the number of inland fishes for the country to 124 (Table 1). There are 1358 species of shore fishes reported for the TEP biogeographic area (Zapata \& Robertson 2007; Robertson \& Allen 2015) and the MUHNES houses representatives of about 16\% (227) of those species. The collection hosts fishes in larval (92 individuals, 2\%), juvenile (443, 12\%) and adult (3265) stages (Table 1).

In this contribution, we extend the known distribution range of the Kreiser's Killifish Profundulus kreiseri Matamoros, Schaefer, Hernández \& Chakrabarty 2012 (Profundulidae). Records for this species were restricted to Chamelecón and Ulúa rivers in Honduras (Matamoros et al. 2012b) and the department of Santa Ana and Chalatenango, El Salvador (McMahan et al. 2013; Salgado Maldonado et al. 2014; Mendoza-Franco et al. 2015; Pinacho et al. 2015). The new records are from Morazán, northeast El Salvador. At the regional scale, we also recommend extending the distribution range of the Congo Sea-Catfish Cathorops fuerthii (Steindachner 1876) (Ariidae) to the coast of El Salvador, as it previously was reported to occur from Panama Bay to Costa Rica (Robertson \& Allen 2015). Finally, the Star Silverside Atherinella starksi (Meek \& Hildebrand 1923) (Atherinopsidae) is herein reported for locations in the departments of La Unión and La Libertad, complementing its previously reported distribution range, sensu Robertson \& Allen (2015), from Ecuador to Nicaragua, and further to Mexico. The El Salvador records reduce the large gap in distribution records for this species that existed between the latter two countries.

\section{Discussion}

The MUHNES ichthyology collection hosts a modest, but relevant number of specimens to the scientific community. They constitute a reference for the taxonomic identification and occurrence record of species in El Salvador. In this regard, the collection represents a potential source of information regarding to the ecological and biological traits of each species by providing information about temporal and spatial changes on species distributions within the country. For El Salvador, the MARN (2016) reported a total of 587 species. Our assessment supports the occurrence of 47 additional species, reaching a total of 634 species, for which 248 species (39\%) have voucher specimens in the MUHNES ichthyology collection. This contribution fills gaps about the knowledge of fish biodiversity in the country, and offers a new perspective about distribution patterns of fish species, at both local and regional scales. Both are of paramount importance considering that effective strategies for management and species conservation must be based on accurate information.

The MUHNES ichthyology collection is the largest in El Salvador with 248 species and 3791 specimens. The Instituto de Ciencias del Mar y Limnología (ICMARES) of the Universidad de El Salvador has the second largest collection of the country with about 2372 specimens and 212 species (Chicas-Batres \& González-Leiva 2016). Paradoxically, some international collections have a similar or greater number of specimens from El Salvador than its two national collections combined (see Chicas-Batres \& González-Leiva 2016). Records of fish specimens from all those collections are highly important for the understanding of fish biodiversity in El Salvador, and cooperation 
should be pursued. Therefore, we suggest combining efforts to integrate information and make it accessible through an open access media (e.g., online databases), and incorporate it to similar initiatives such as FishBase (Froese \& Pauly, 2017), FishNet 2 (http://www.fishnet2.net/ index.html), the computerized form of the Catalog of Fishes (Eschmeyer, 2018), the Global Biodiversity Information Facility (GBIF, https://www.gbif.org/) or WORMS (Horton et al. 2018; http://www.marinespecies.org/index.php). In this sense, access to the collection data may reduce the redundancy and replication of research efforts and can allow more efficient allocation of resources, which in most cases are limited. Therefore, digitization of the data of the MUHNES ichthyology collection is an admirable first step towards the dissemination of the knowledge on fishes from the country.

Future perspectives of the museum must respond to national plans for research and biodiversity conservation. Primary interest must be directed to the collection of specimens that comprehensively represent the ichthyological diversity of El Salvador, including if possible tissue samples for DNA extraction, which can help to solve taxonomic conundrums in some species complex or groups (Robertson et al. 2017). It is critically important to increase the number of specimens and species particularly for freshwater taxa. Changes in land use and pollution (Sala et al. 2000) have affected the majority of freshwater ecosystems in El Salvador leading species towards the categories of collapsed, endangered or critically endangered (Crespín \& Simonnetti 2015; 2016), exerting a strong pressure on the biodiversity. On the other hand, collection efforts must consider gathering specimens from the great diversity of environments in El Salvador, including lakes, rivers, estuaries, rocky, sandy and muddy shores, and offshore habitats. Deep sea environments in particular have recently shown a great diversity of fishes (Fuentes et al. 2015; Robertson et al. 2017) and still harbour undescribed species; for instance, based on a specimen from El Salvador, the species Leptoderma ospesca Angulo, Baldwin \& Robertson 2016 was recently described for the Pacific Central American coast (Angulo et al. 2016).

Early life stages of fishes should also be taken into consideration as part of the process to increase collection acquisitions; early stages of fishes can provide valuable information on the taxonomy, phylogeny and ecology of species. In El Salvador and more generally in the TEP, there is a lack of taxonomic information about early life stages of fishes. The MUHNES ichthyology collection hosts a relative small number of eggs and larvae. However, the highly variable nature of fish eggs and larval traits make them difficult to identify using only morphological characters (Thiel et al. 2009; Ko et al. 2013; Leis 2015), and the collection of material for DNA barcoding should be consider. Eventually, the MUHNES ichthyology collection could focus efforts on being a reference collection in the region, promoting the incorporation other biogeographical areas within the TEP, and when possible, from other regions in the world, as well as specimens from other taxonomic groups, such as Myxini (hagfishes), Petromyzontida (lampreys), Holocephali (chimaeras) and Sarcopterygii (lobe-finned fishes).

A strong collection focused on fishes from El Salvador will promote new research areas at MUHNES such as the delineation of biogeographic areas, detection of areas with high species richness (hot spots) or endemicity (e.g. Zapata \& Robertson 2007; Abell et al. 2008; Robertson \& Cramer 2009; Matamoros et al. 2012a; Matamoros et al. 2015; Robertson et al. 2017) and genetic assessments of populations (McMahan et al. 2013; McMahan et al. 2014; Robertson et al. 2017). Furthermore, adding ecological data to the fish collection sites can favour the development of models to predict changes in distributions due to environmental conditions expected under different climate change scenarios (Sala et al. 2000).

In conclusion, the first qualitative and quantitative assessment of the MUHNES ichthyology collection registered 3791 individuals in 1005 lots that encompass 276 taxa, of which 248 are identified to the species level. A total of 47 species records are added to the national checklist of fishes (MARN 2016) and the known distributions of three species (Profundulus kreiseri, Cathorops fuerthii and Atherinella starksi) are expanded based on MUHNES vouchers from El Salvador. This information is a valuable contribution to the knowledge of the biodiversity from El Salvador and establishes an official starting point for future fish research in the country.

\section{Acknowledgements}

We are grateful to M. Murcia and S. Erdmann for the support to SGM; E. Echeverría for the logistic support in the MUHNES; X. Pocasangre for laboratory assistance; A. E. Gómez-González and W. Martínez-Pinto, colleagues who share our enthusiasm and passion for fishes; S. González-Rosales for his invaluable legacy and contribution to SGM; and K. Sambrook, B. Arbizu and Mark Sabaj for comments that improved the quality of the manuscript. 


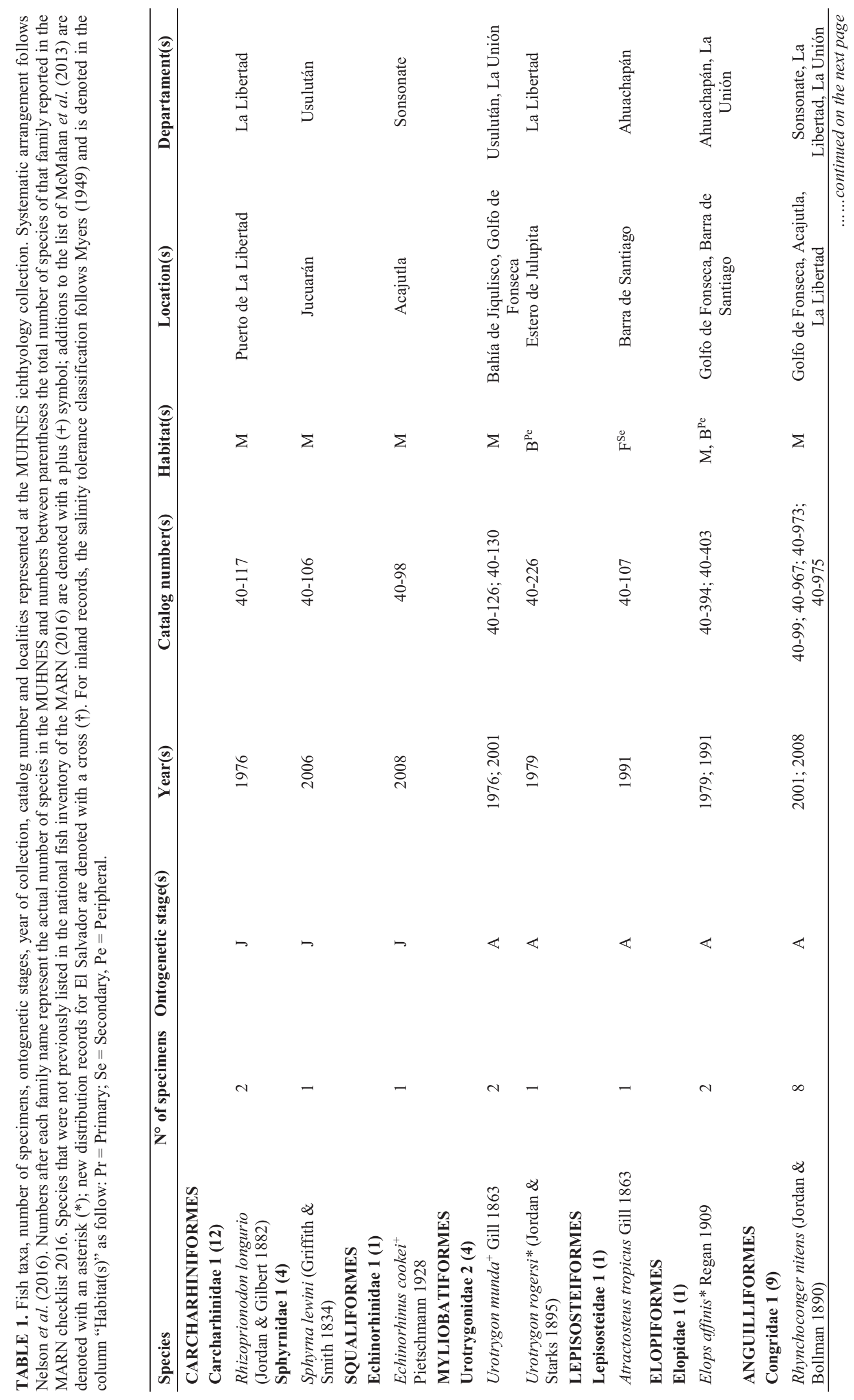




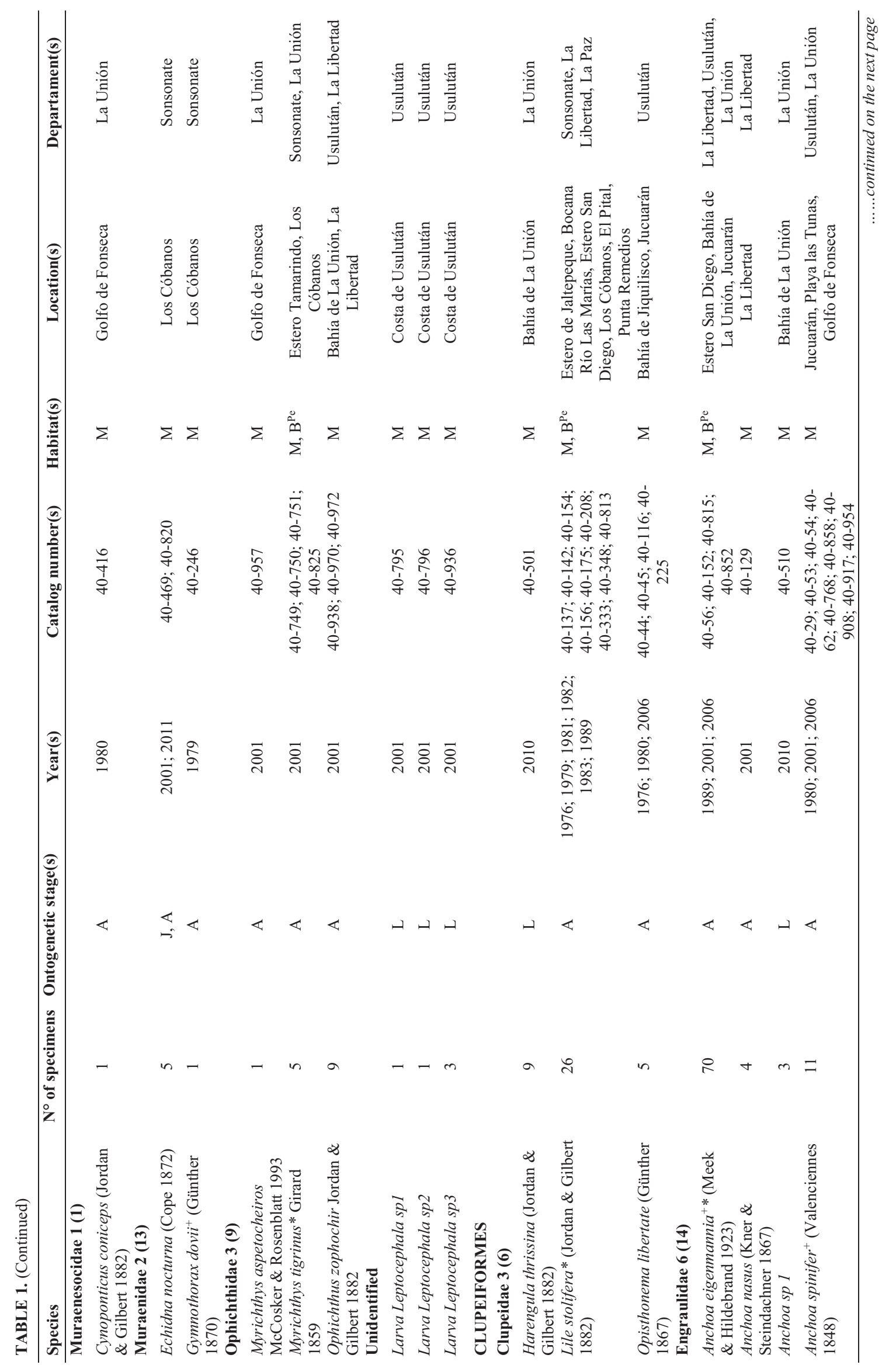




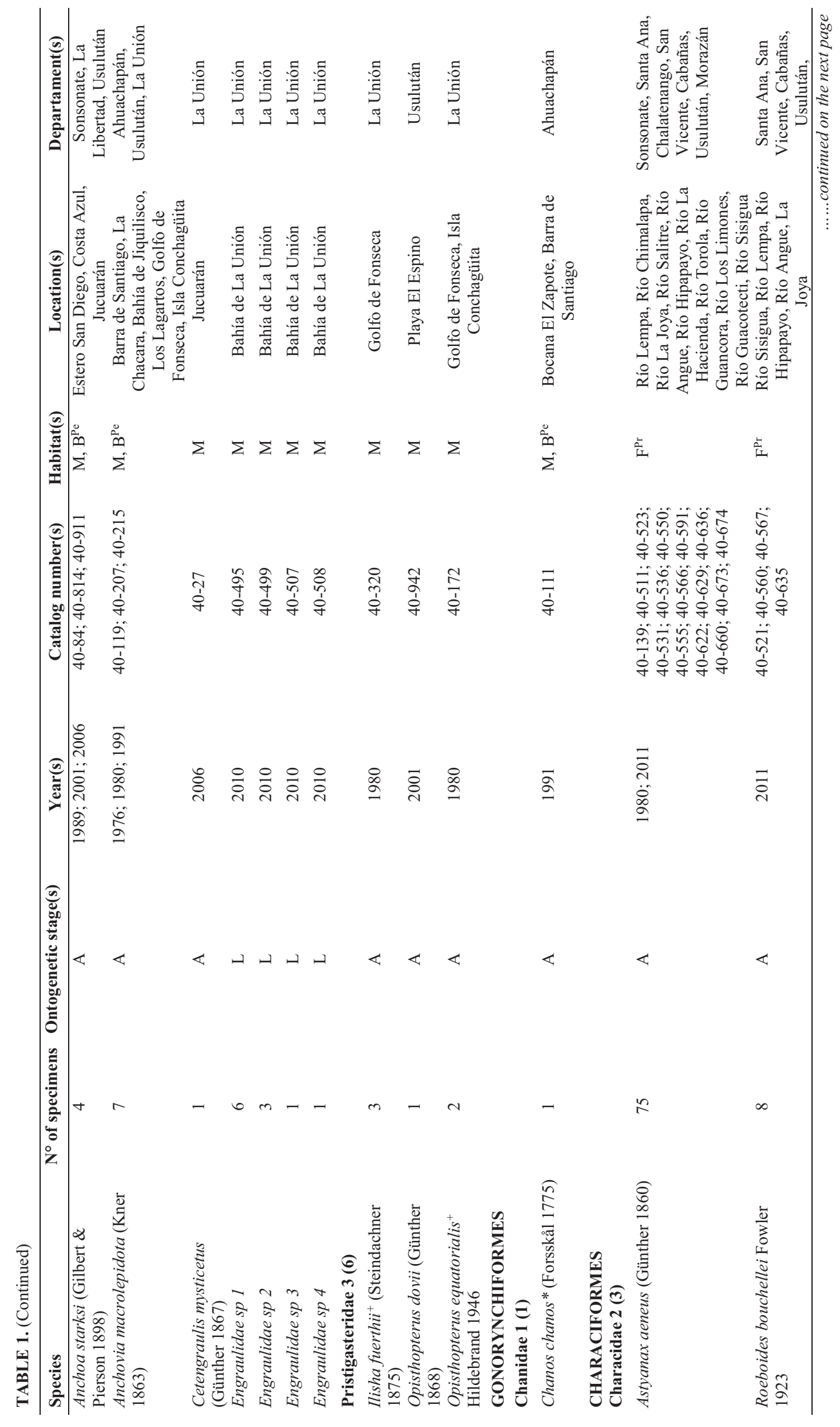




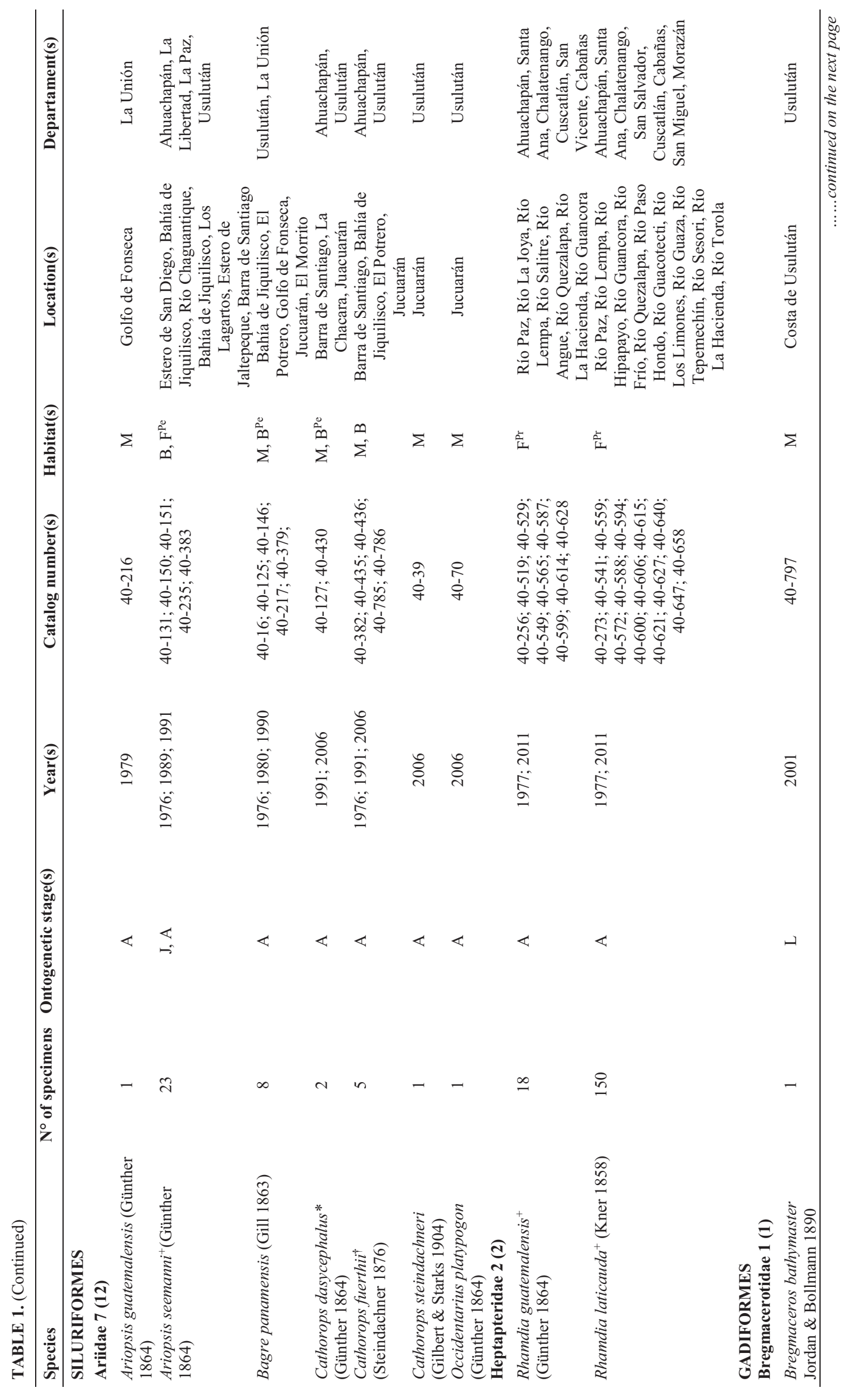




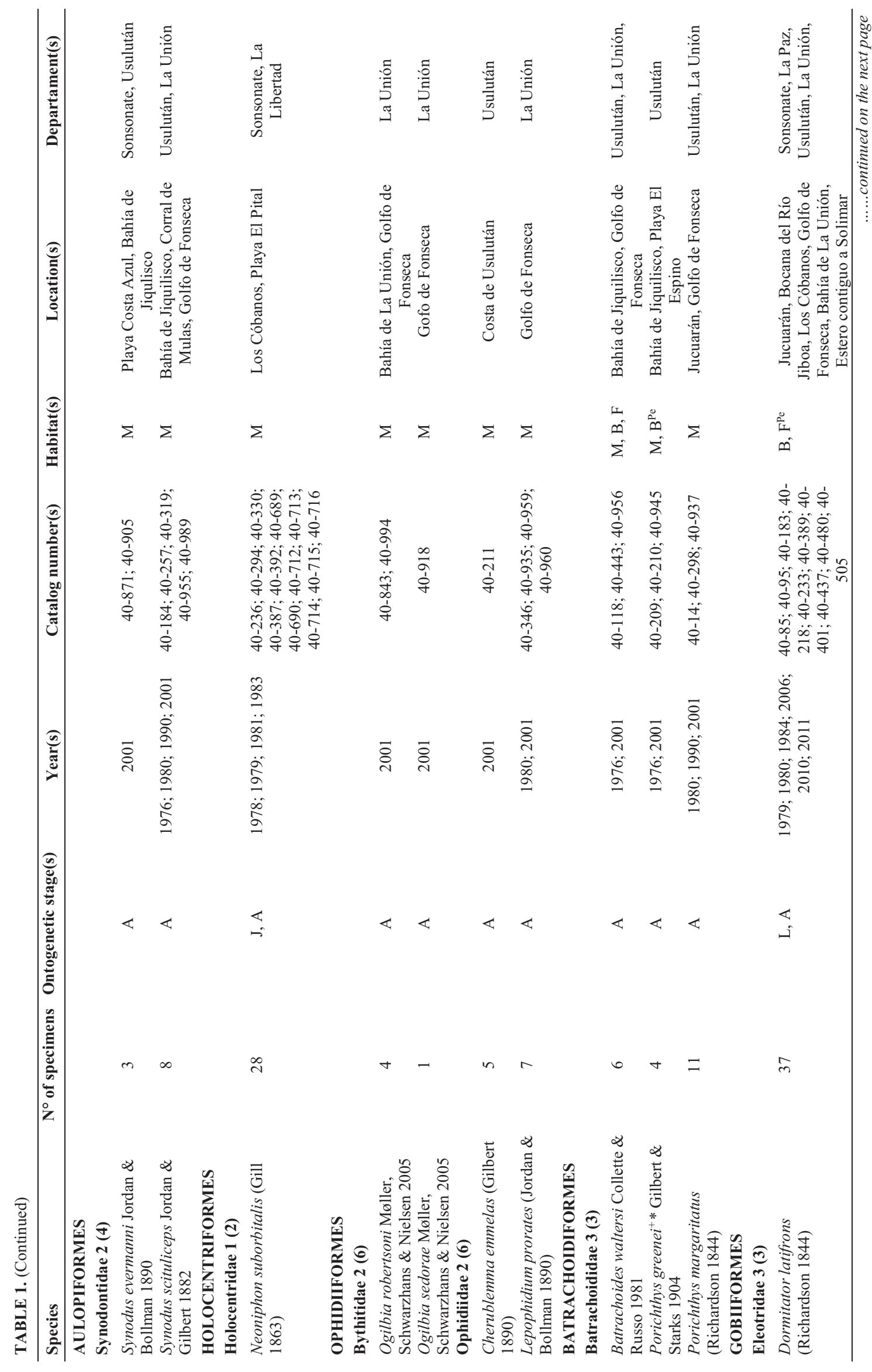




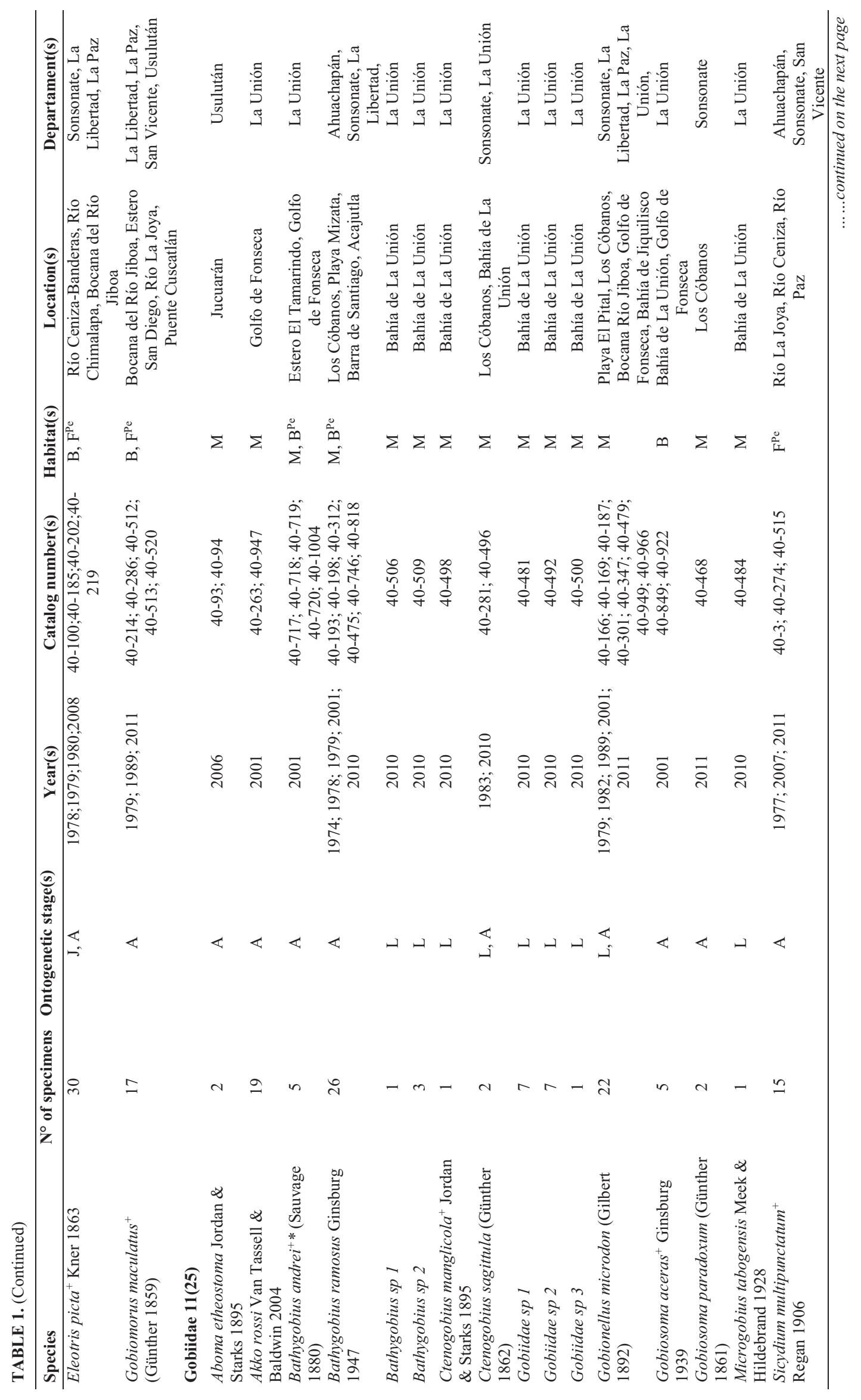




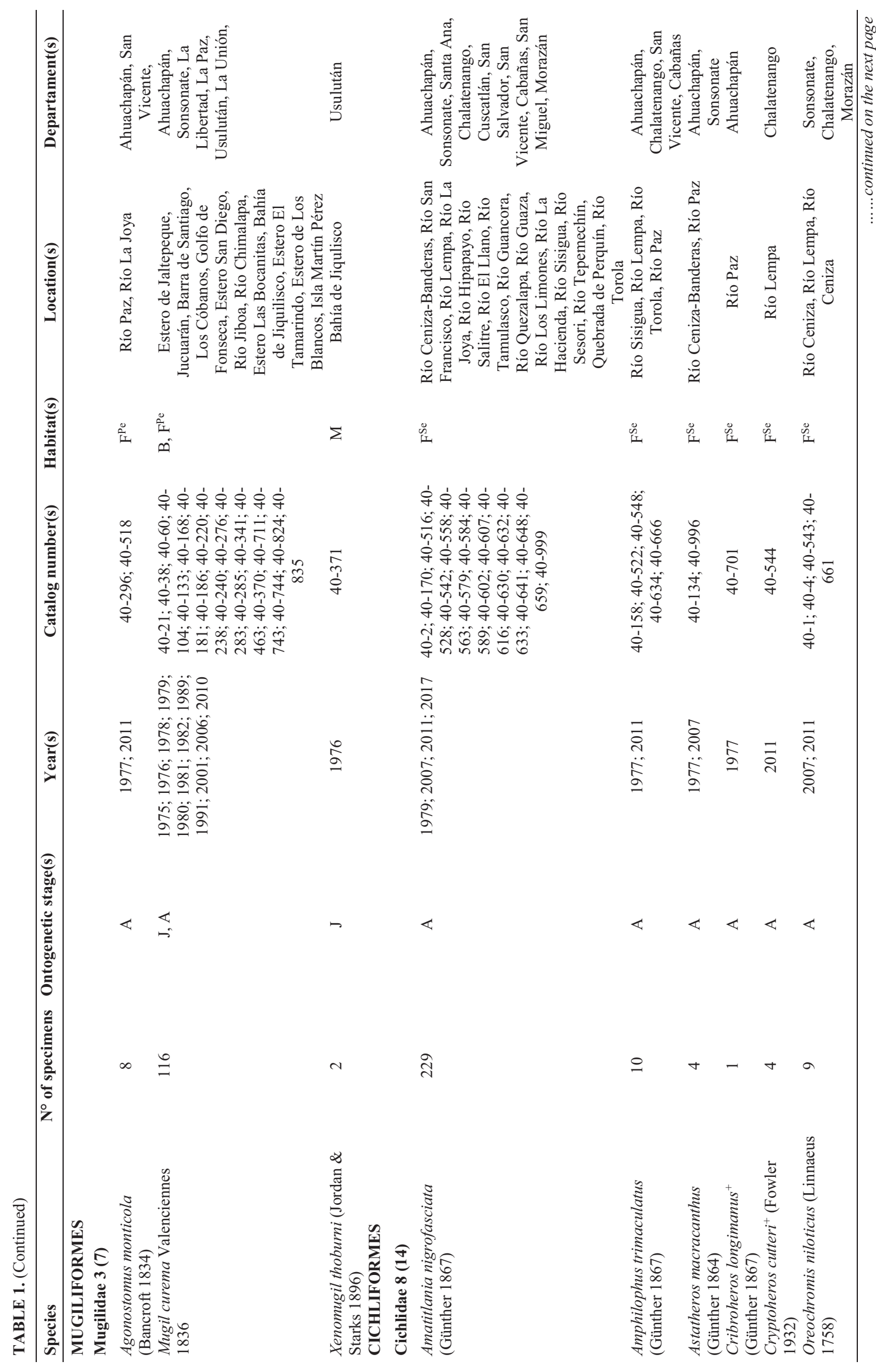




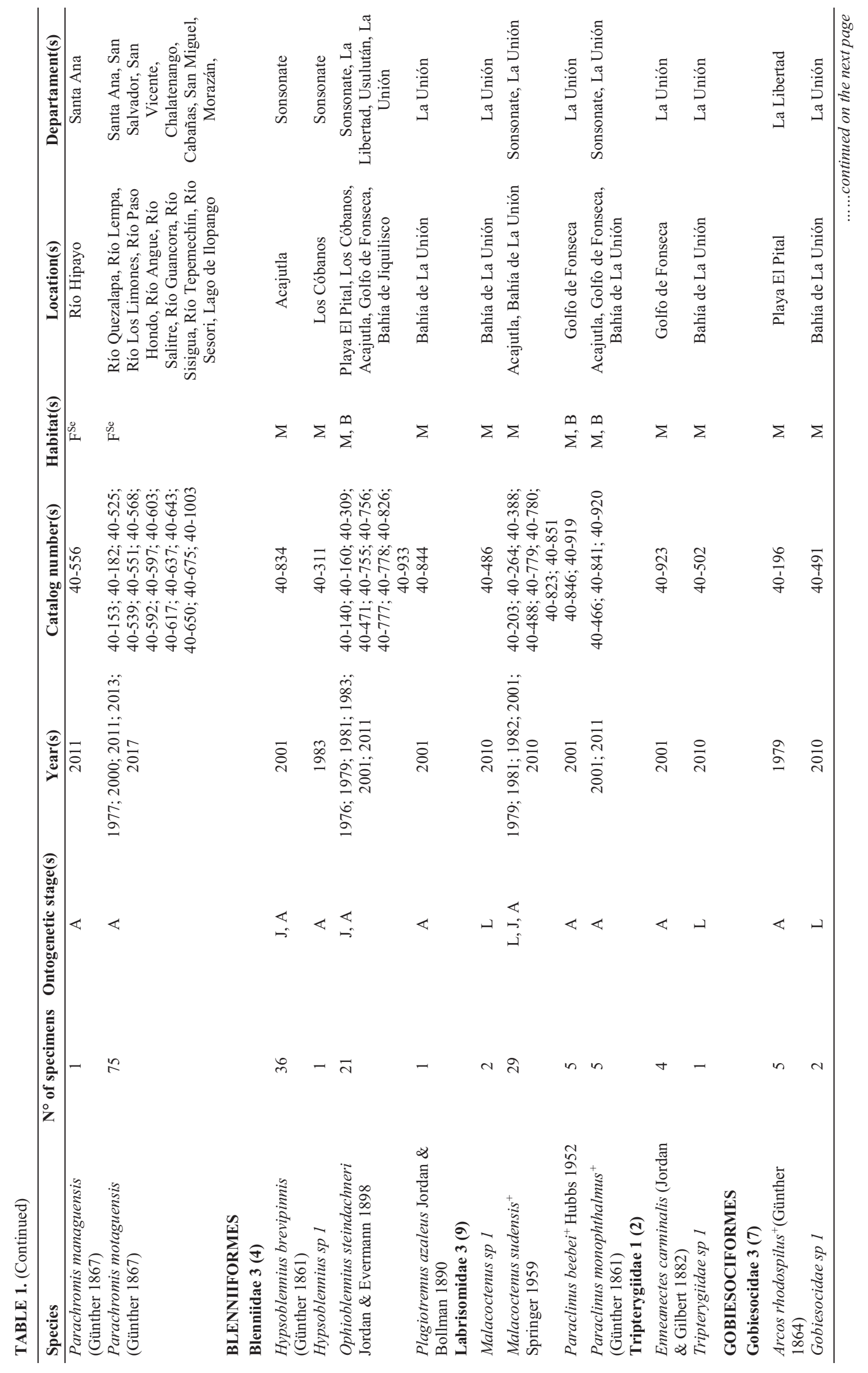




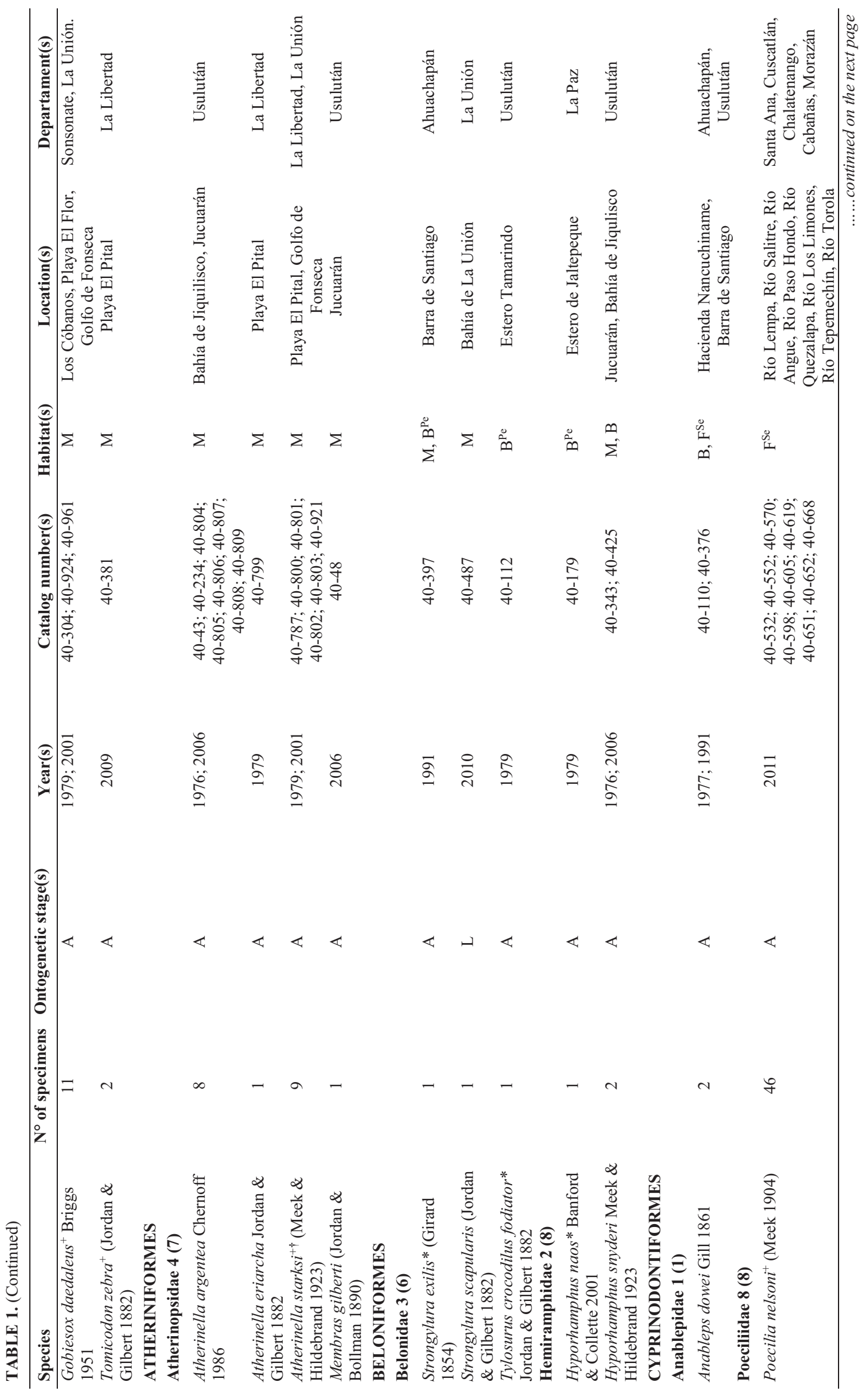




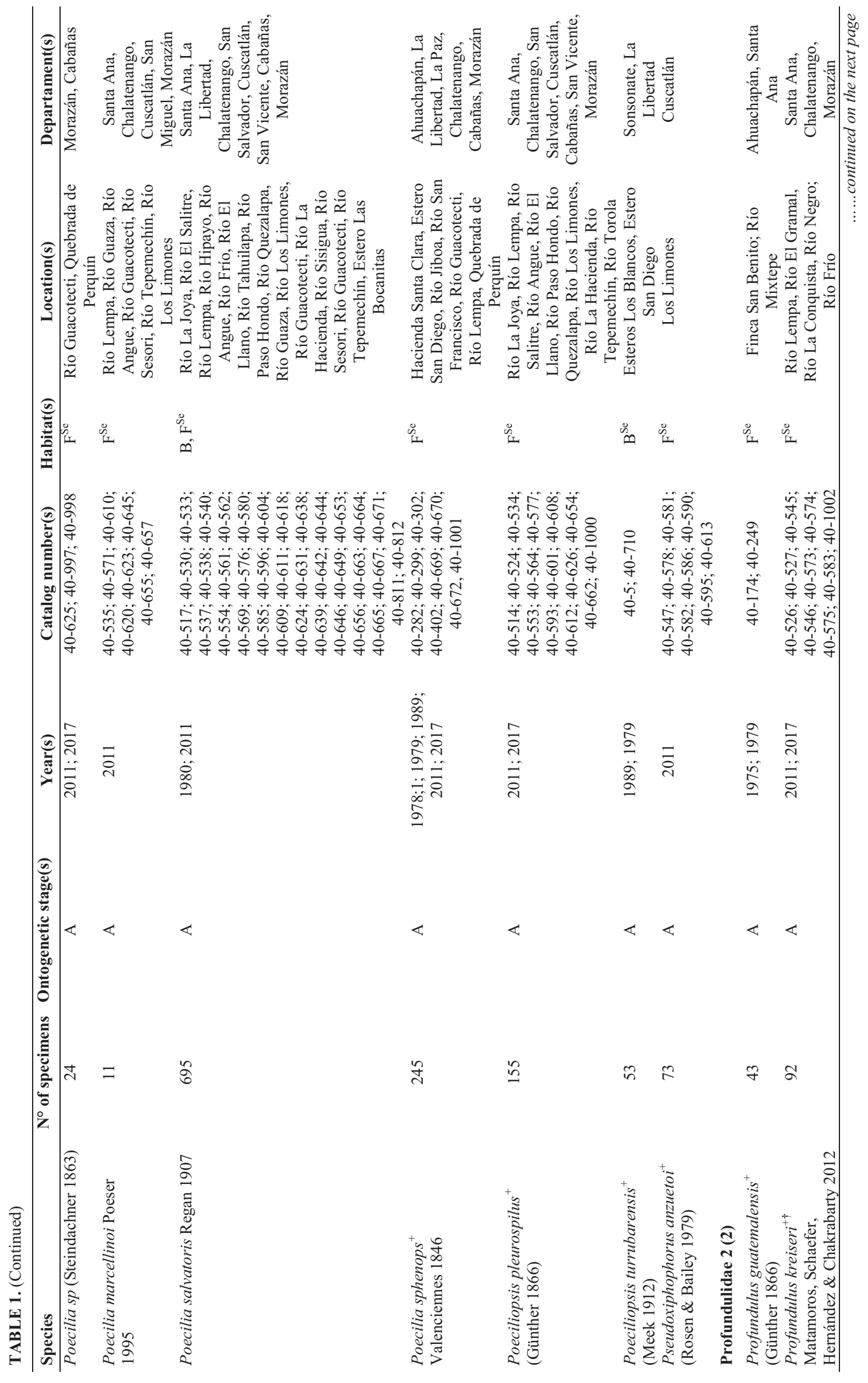




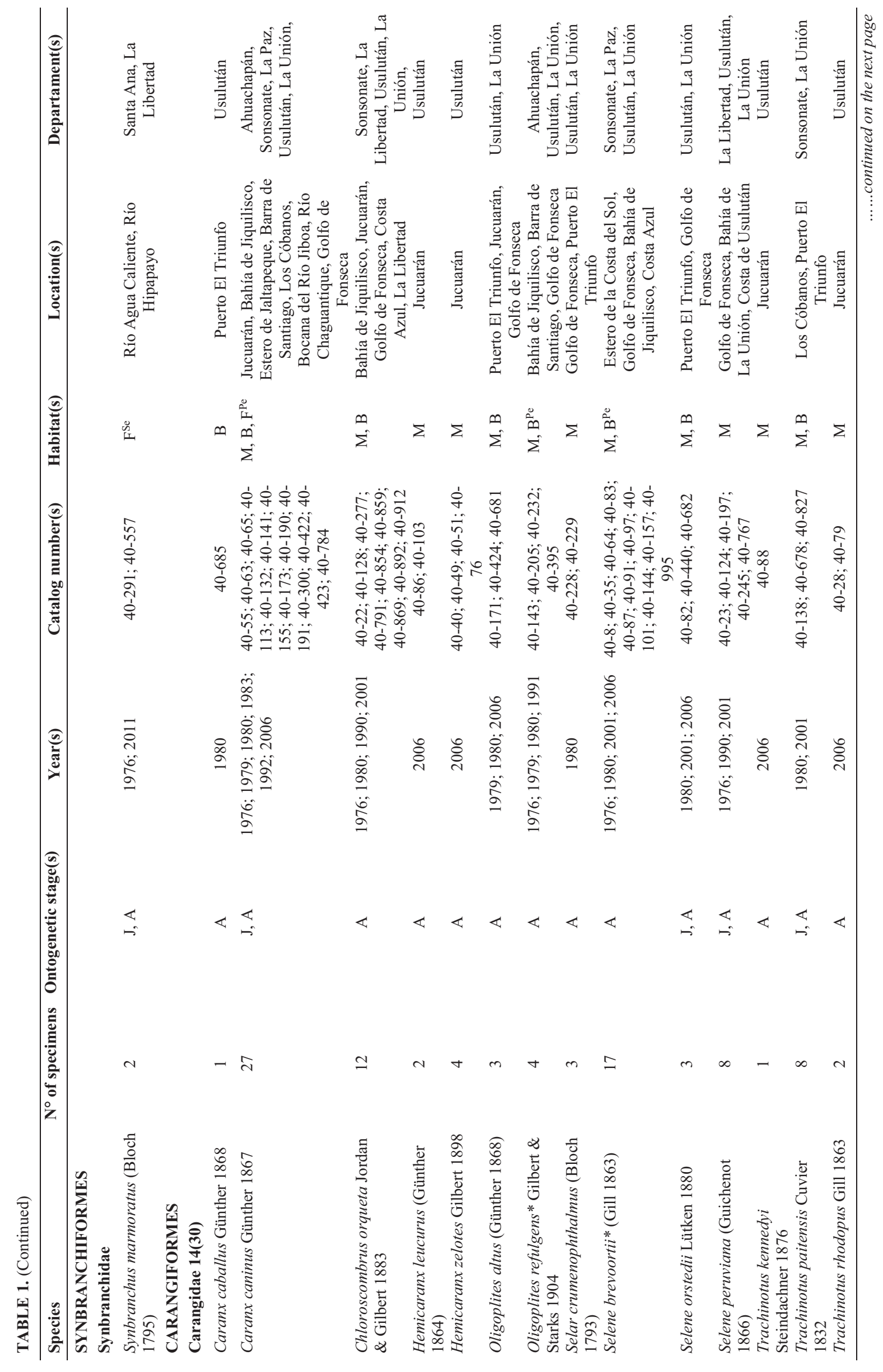




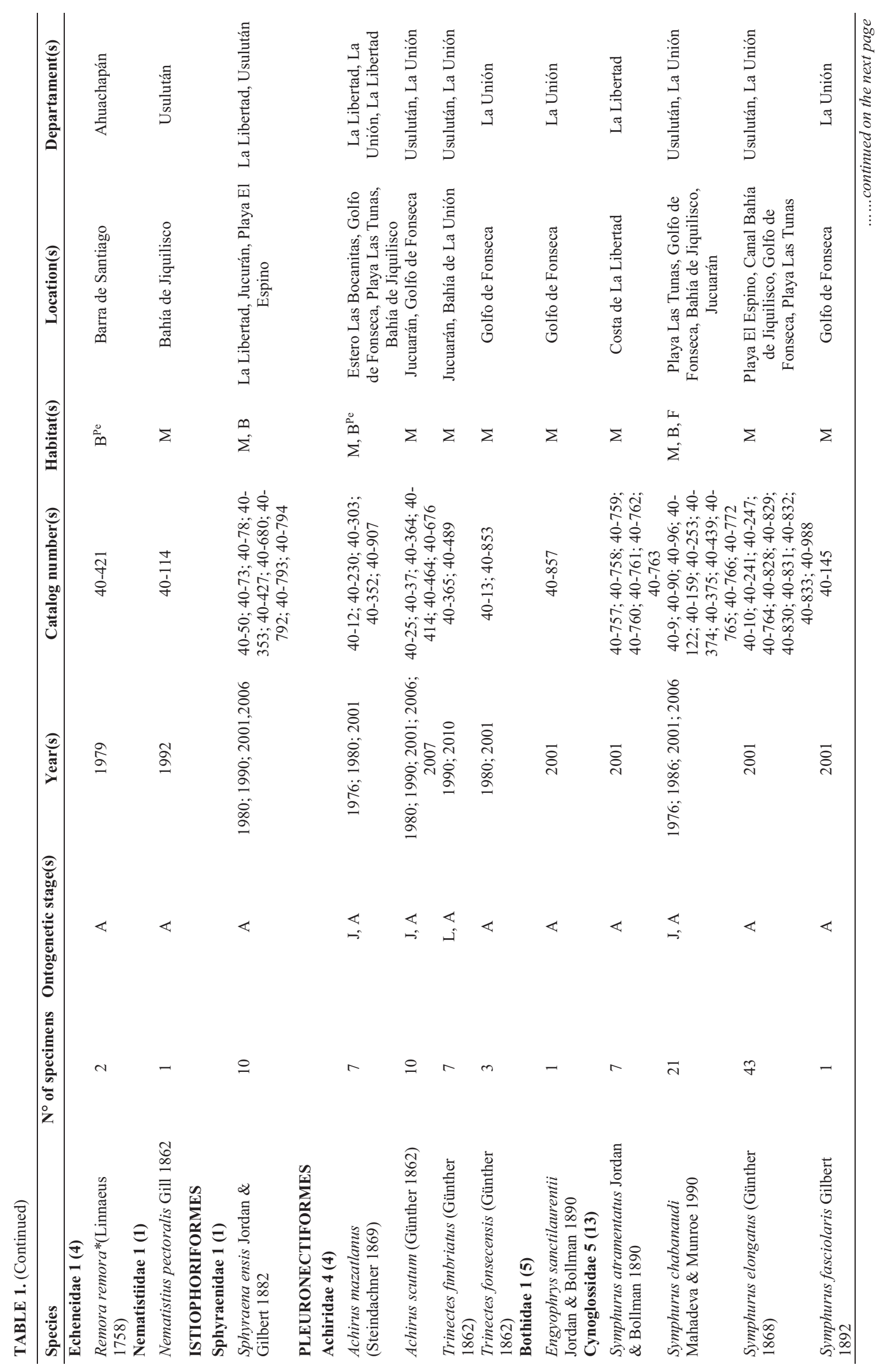




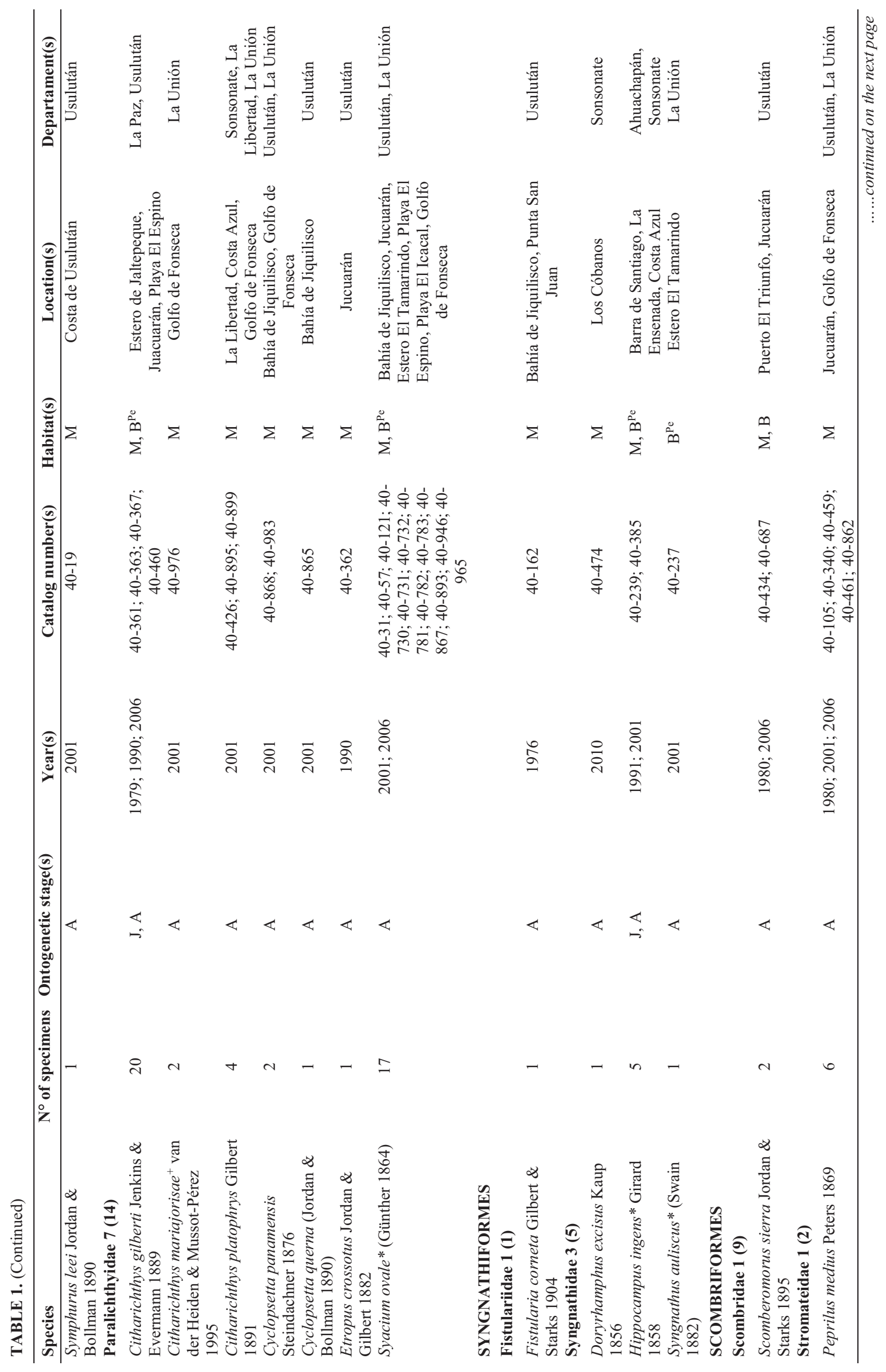




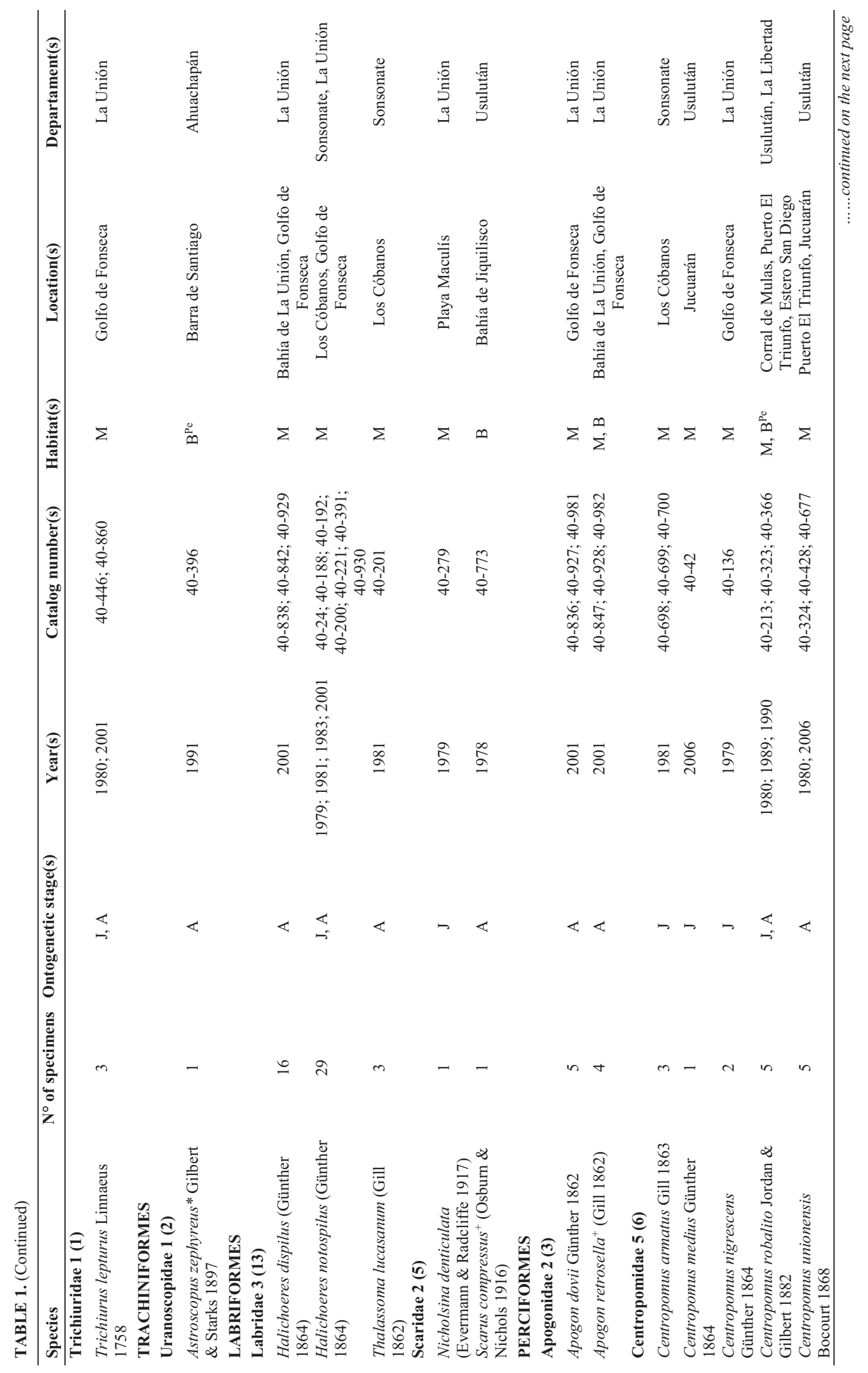




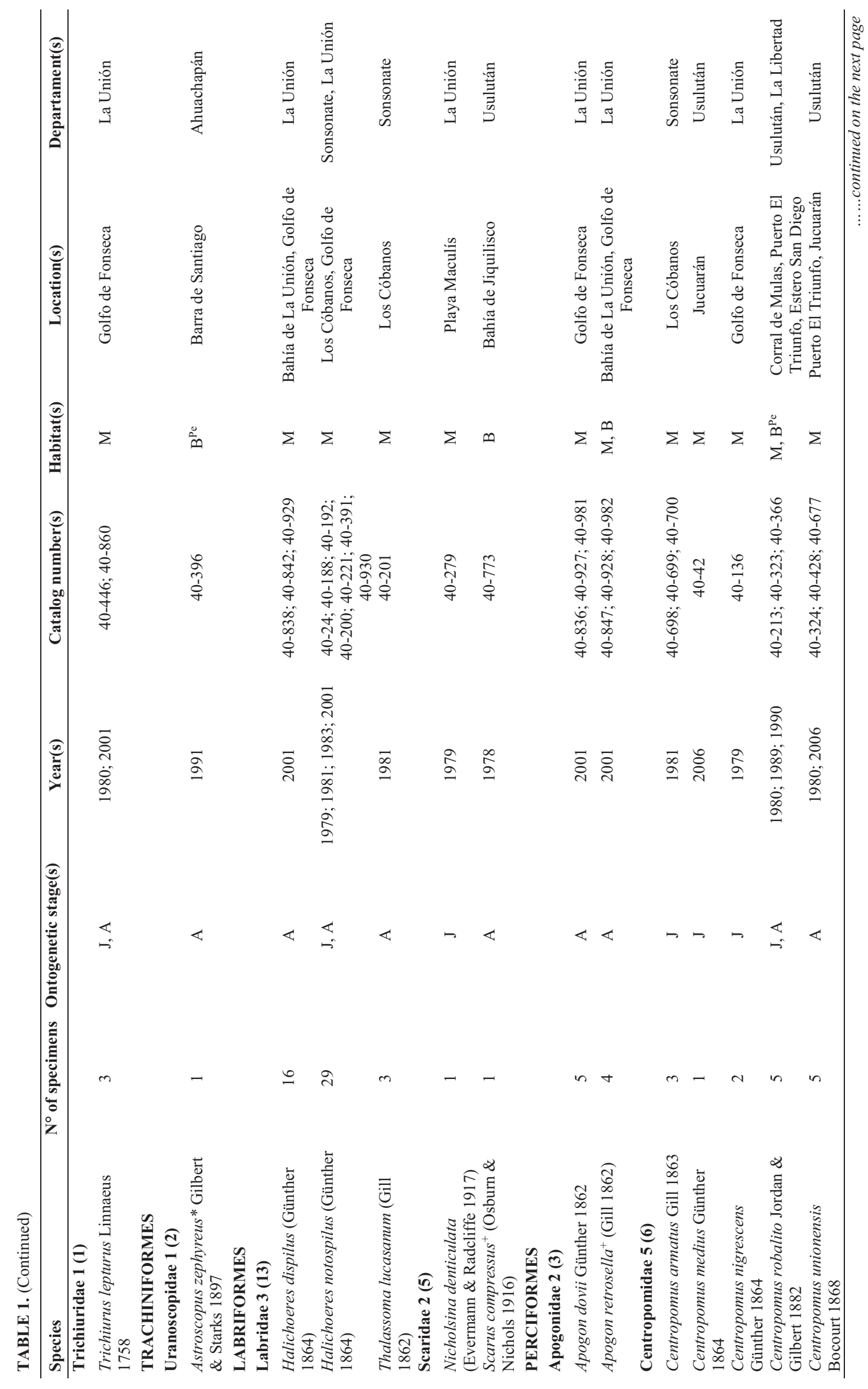




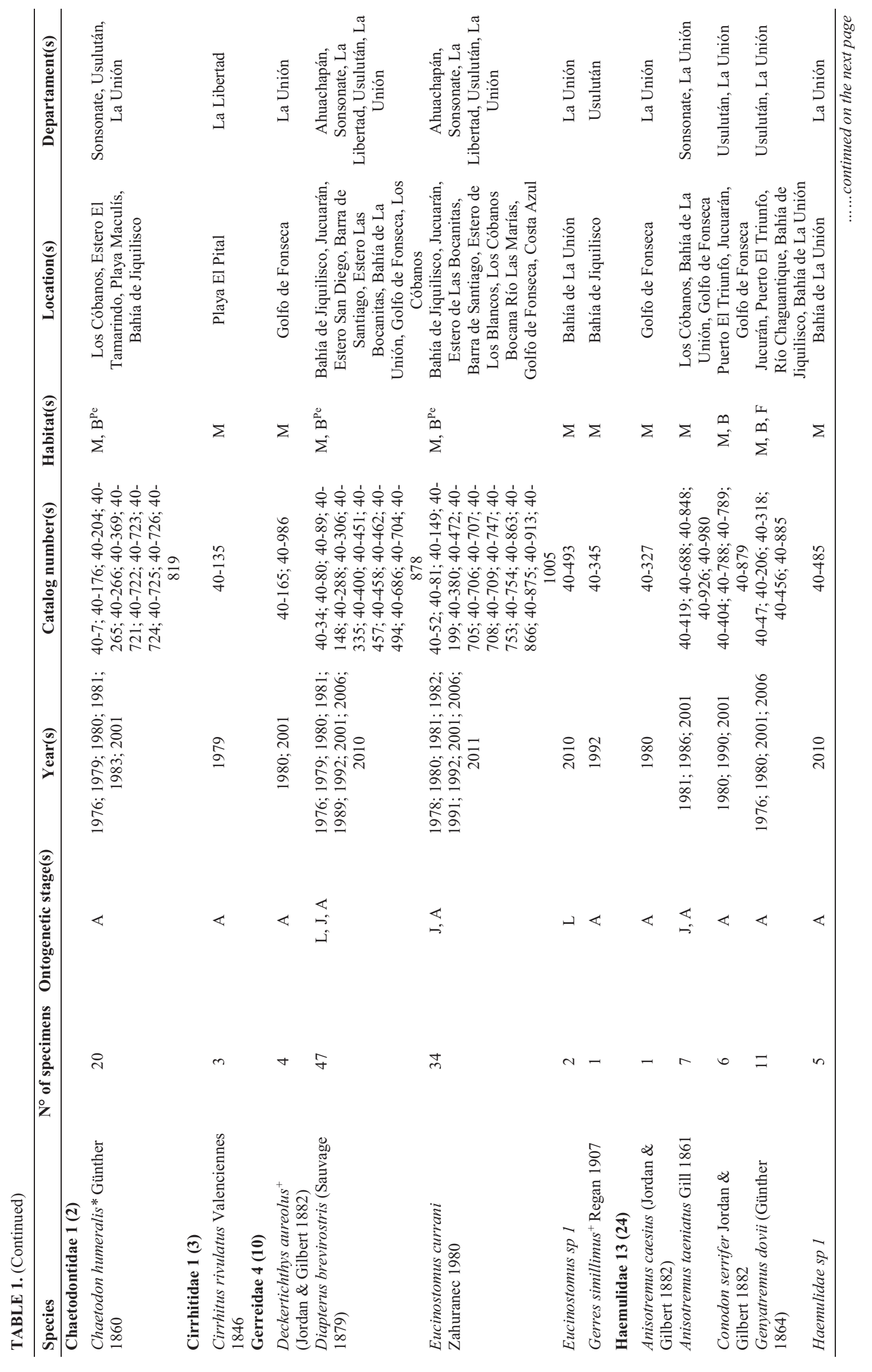




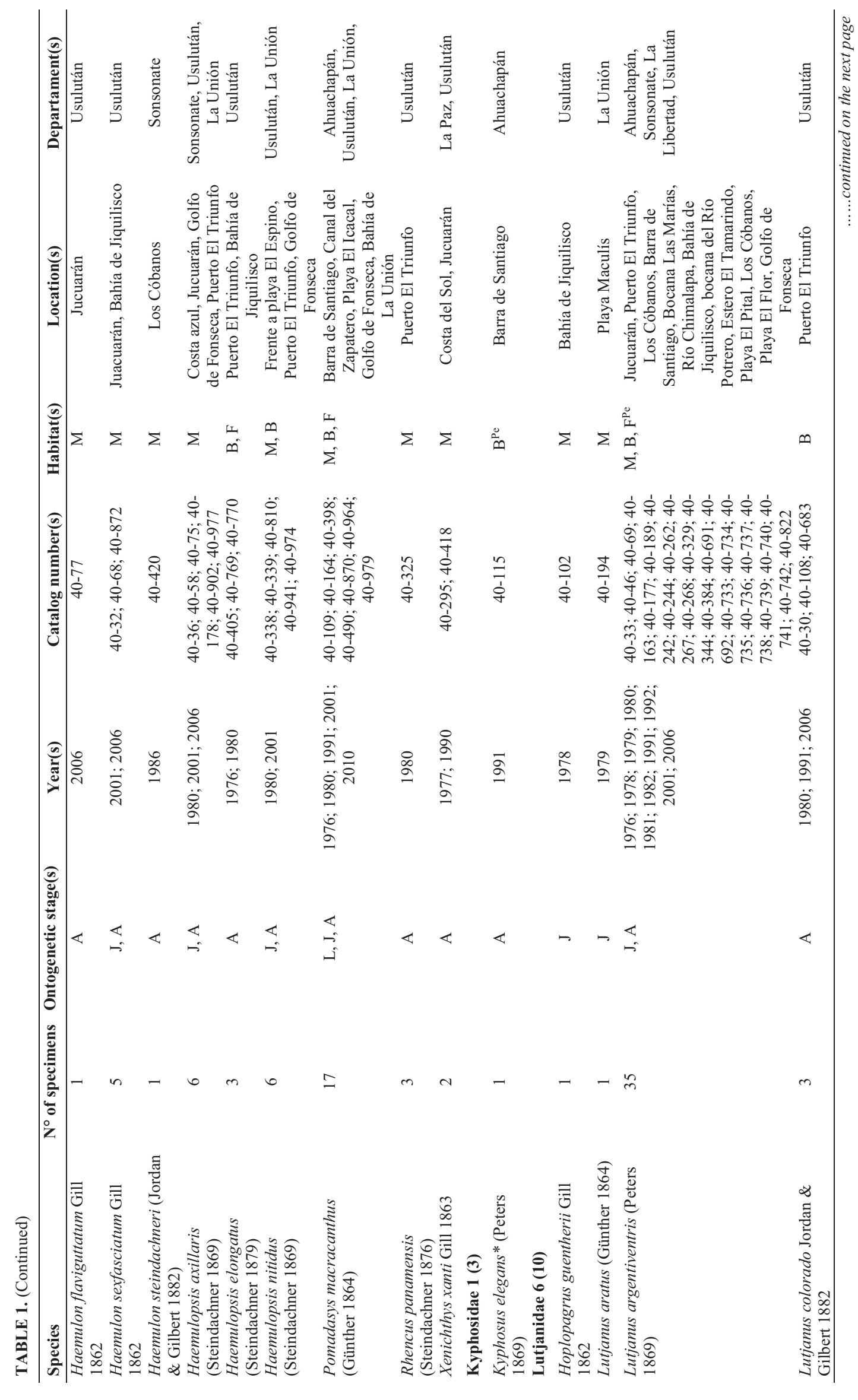




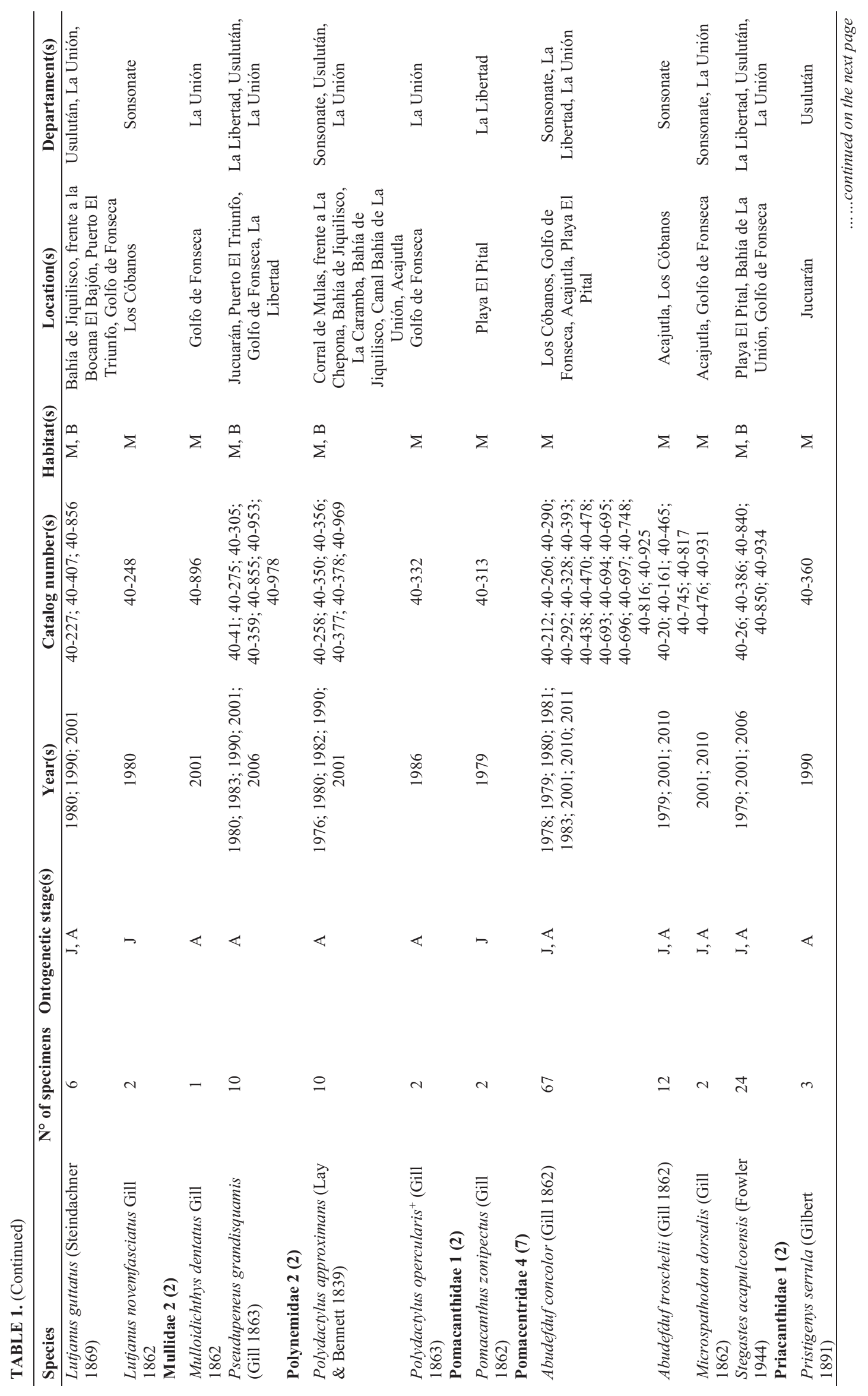




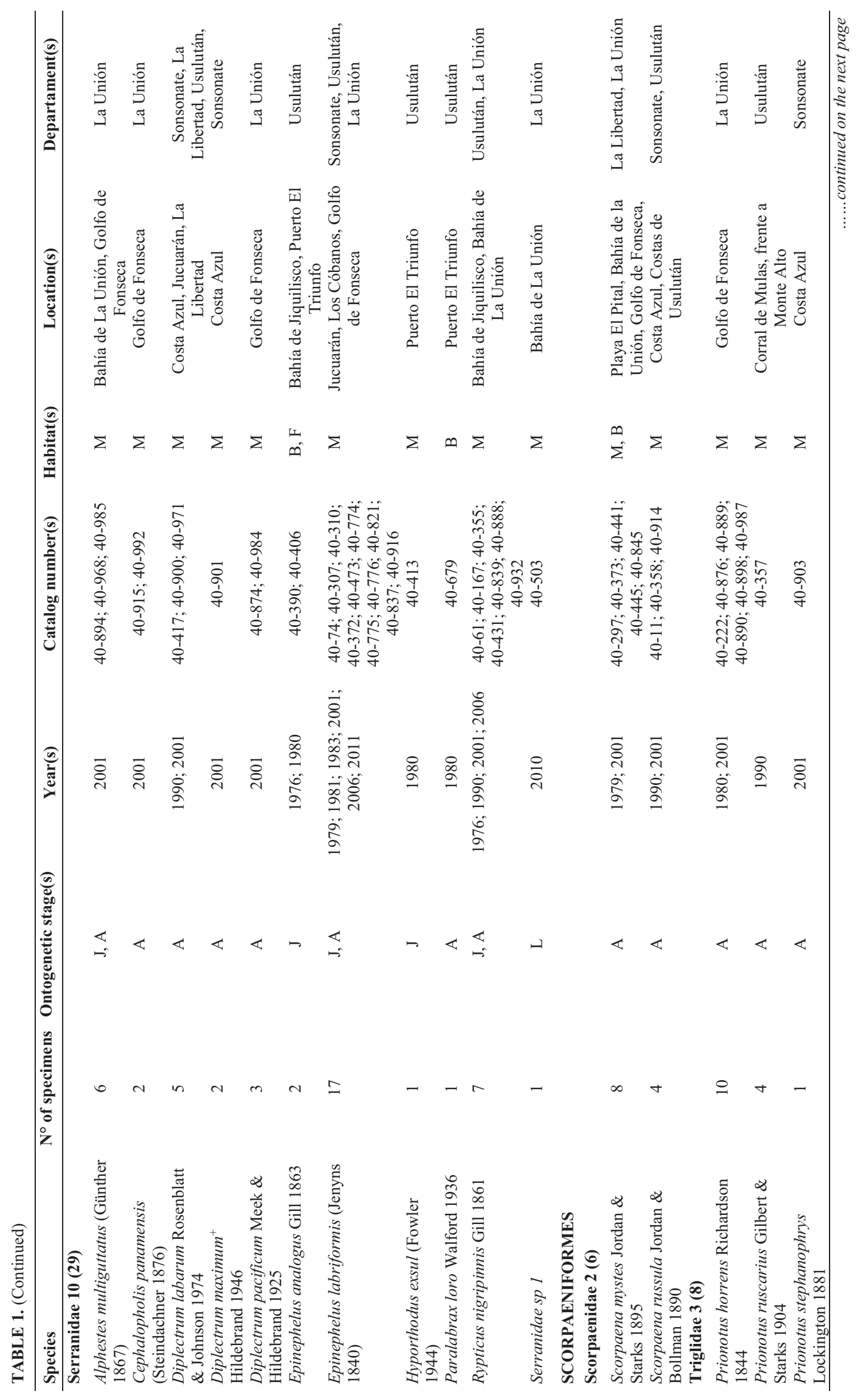




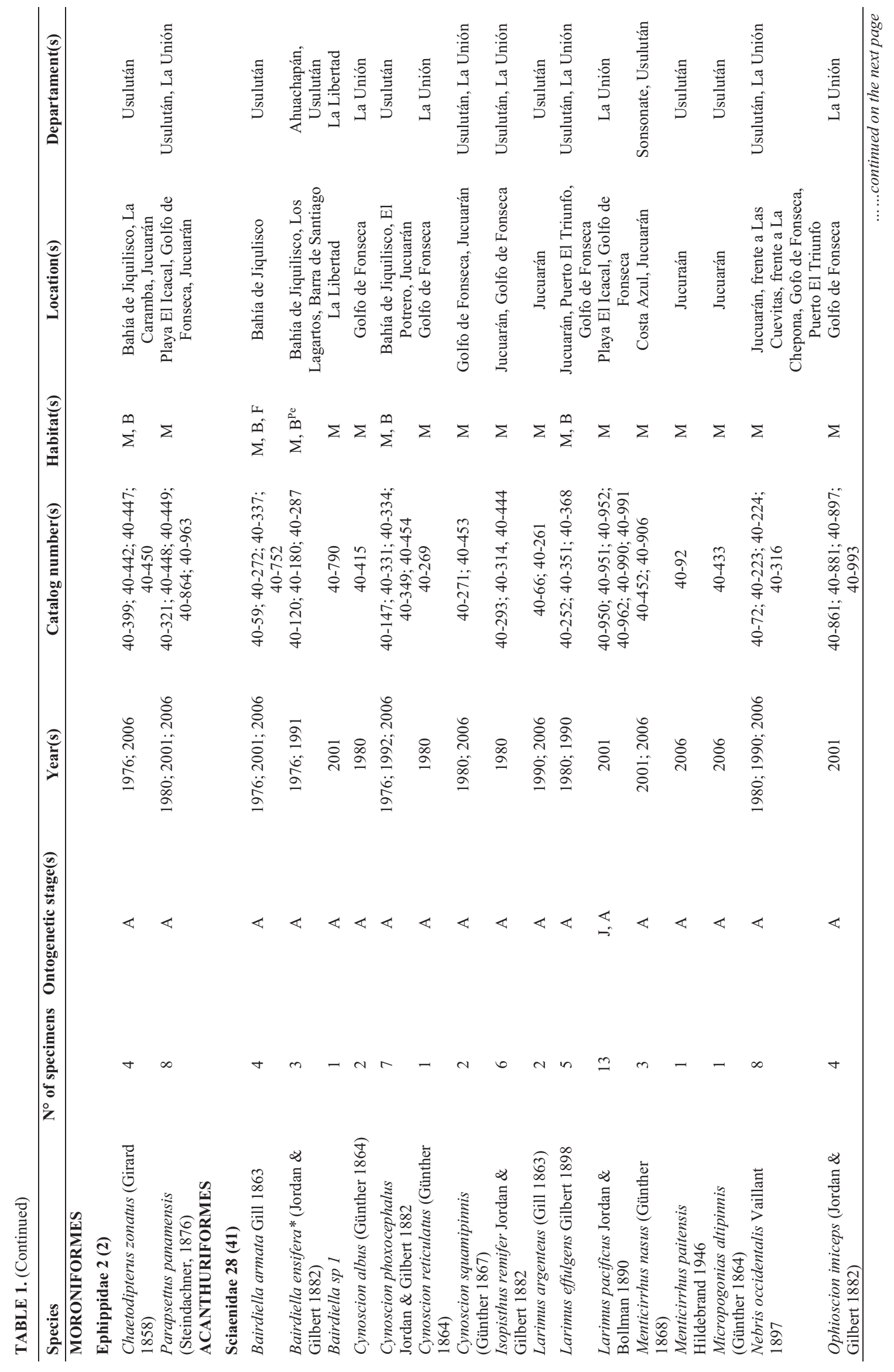




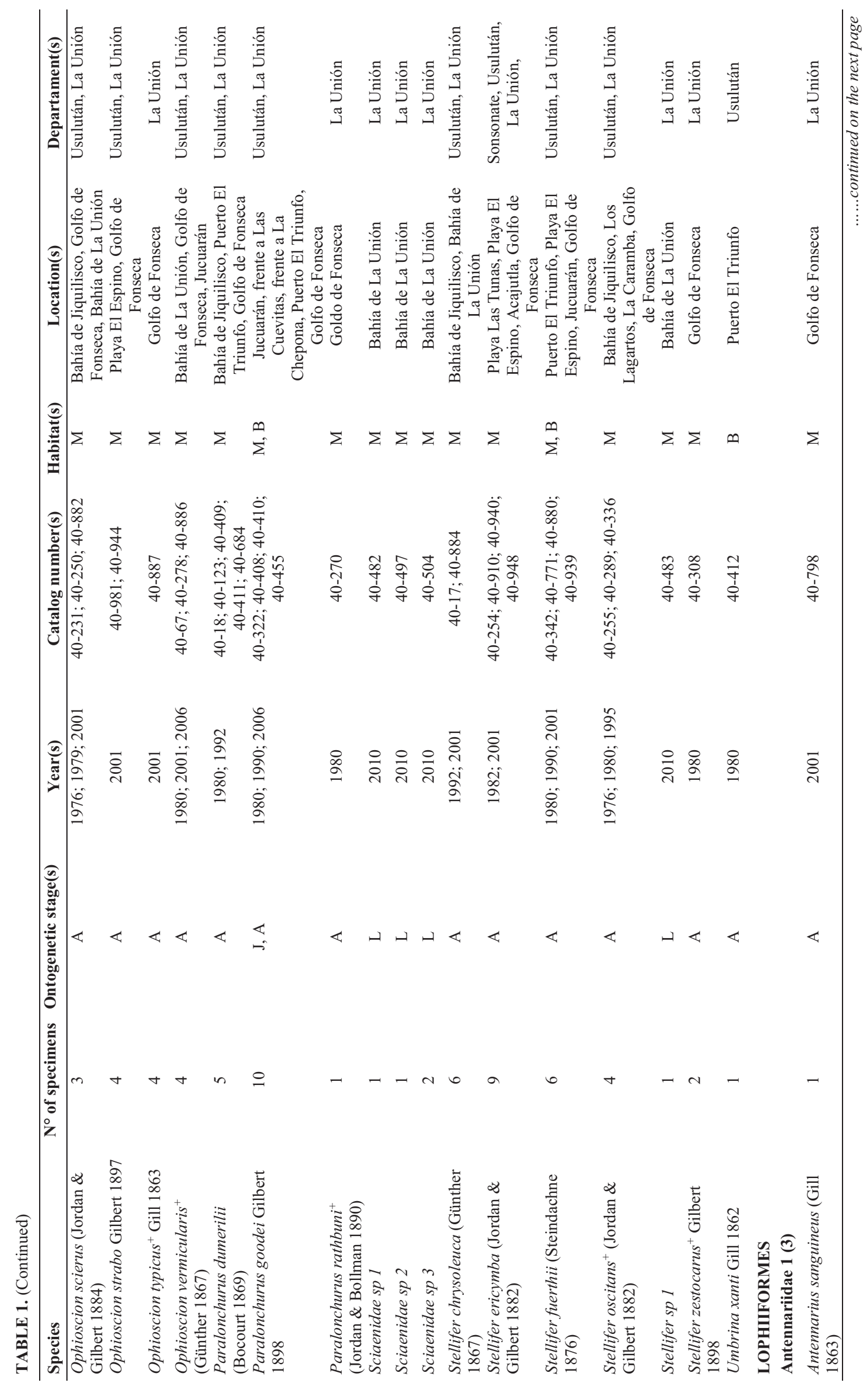




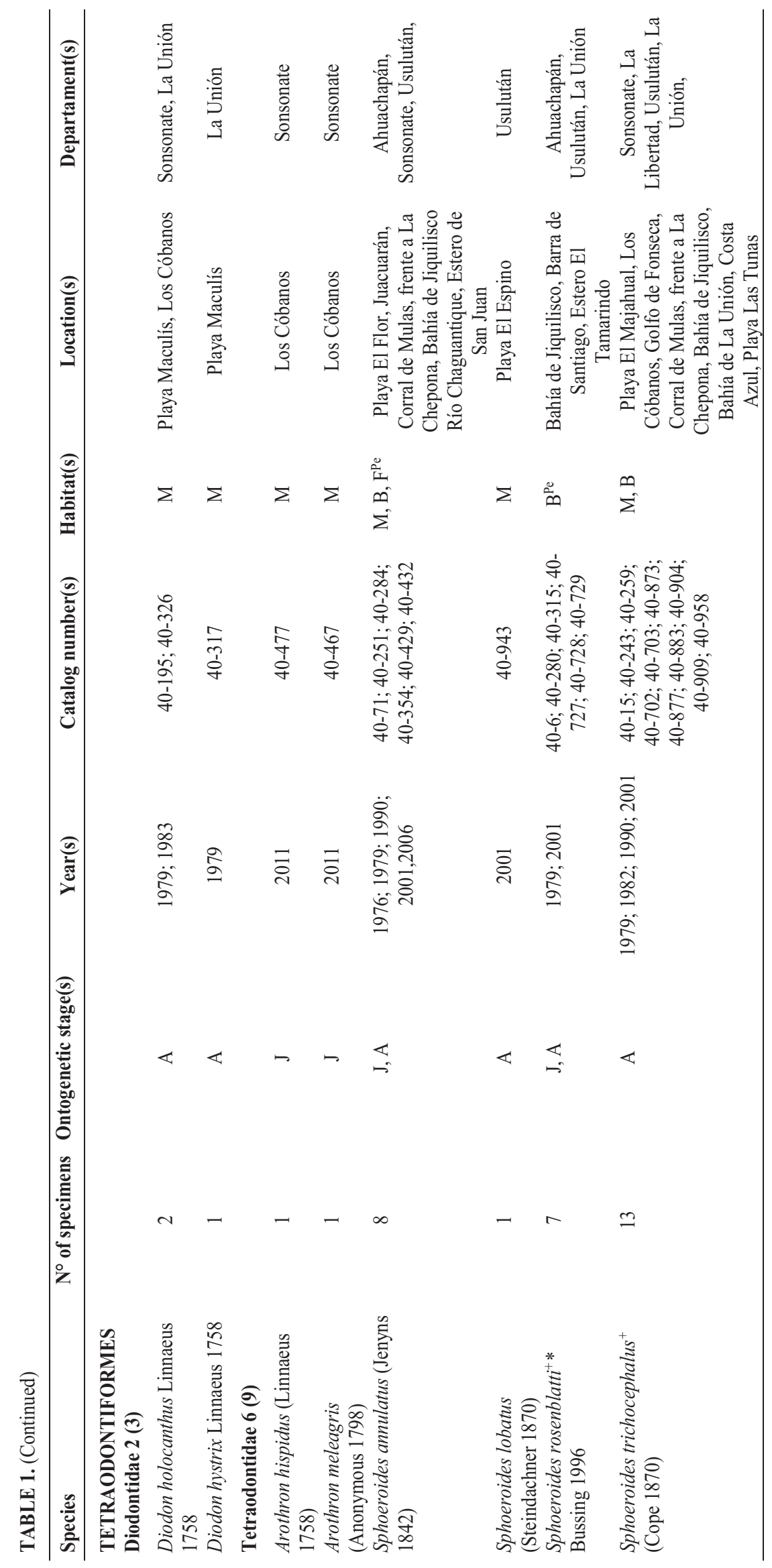




\section{References}

Abell, R., Thieme, M.L., Revenga, C., Bryer, M., Kottelat, M., Bogutskaya, N., Coad, B., Mandrak, N., Contreras Balderas, S., Bussing, W., Stiassny, M.L.J., Skelton, P., Allen, R.G., Unmack, P., Naseka, A., Ng., R., Sindorf, N., Robertson, J., Armijo, E., Higgins, J.V., Heibel, T.J., Wikramanayake, E., Olson, D., López, H.L., Reis, R. E., Lundberg, J.G., Sabaj, M.H. \& Petry, P. (2008) Freshwater Ecoregions of the World: A New Map of Biogeographic Units for Freshwater Biodiversity Conservation. BioScience, 58 (5), 403-404. https://doi.org/10.1641/B580507

Alda, F., Reina, R.G., Doadrio, I. \& Bermingham, E. (2013) Phylogeny and biogeography of the Poecilia sphenops species complex (Actinopterygii, Poeciliidae) in Central America. Molecular Phylogenetics and Evolution, 66, 1011-1026. https://doi.org/10.1016/j.ympev.2012.12.012

Álvarez, F.S., Recinos, H.M. \& Henríquez, W.Y. (2013) First record of Heterandria anzuetoi (Cyprinodontiformes: Poeciliidae) in El Salvador. Revista Mexicana de Biodiversidad, 84, 1335-1337. https://doi.org/10.7550/rmb.31310

Álvarez, F.S., Matamoros, W.A. \& Chicas, F.A. (2017) The contribution of environmental factors to fish assemblages in the Río Acahuapa, a small drainage in Central America. Neotropical Ichthylogy, 15 (3), E170023. [published online] https://doi.org/10.1590/1982-0224-20170023

Angulo, A., Baldwin, C.C. \& Robertson, D.R. (2016) A new species of Leptoderma Vaillant, 1886 (Osmeriformes: Alepocephalidae) from the Pacific coast of Central America. Zootaxa, 4066 (4), 493-500. https://doi.org/10.11646/zootaxa.4066.4.10

Barber, R.T, Vijayakumar, A. \& Cross, F.A. (1972) Mercury concentration in recent and ninety-year old benthopelagic fish. Science, 178, 636-639. https://doi.org/10.1126/science.178.4061.636

Bussing, W.A. (2002) Freshwater Fishes of Costa Rica. Editorial Universitaria, San José Costa Rica, 504 pp.

Chicas-Batres, F.A. \& González-Leiva, J.A. (2016) Peces de El Salvador depositados en Colecciones Científicas de Museos y Universidades. In: del Moral-Flores, F.L., Ramírez-Villalobos, A.J., Martínez-Pérez, J.A., González Acosta, A.F. \& Franco-López, J. (Eds.), Colecciones Ictiológicas de Latinoamérica. Facultad de Estudios Superiores Iztacala, UNAM. Sociedad Ictiológica Mexicana A.C., México, pp. 133-150.

Crespín, S.J. \& Simonetti, J.A. (2016) Loss of ecosystem services and the decapitalization of nature in El Salvador. Ecosystem Services, 17, 5-13. https://doi.org/10.1016/j.ecoser.2015.10.020

Crespín, S.J. \& Simonetti, J.A. (2015) Predicting ecosystem risk of collapse: spatial factors that influence risks to tropical ecosystems. Austral Ecology, 40, 492-501. https://doi.org/10.1111/aec.12209

Dalton, R. (2003) Natural history collections in crisis as funding is slashed. Nature, 423, 575. https://doi.org/10.1038/423575a

Echeverría, E.E. (2013) Museo de Historia Natural de El Salvador: Inicio, evolución y futuro. Secretaría de Cultura de la Presidencia, Dirección de Publicaciones e Impresos, San Salvador, El Salvador, 50 pp.

Eschmeyer, W.N., Fricke, R. \& Van der Laan, R. (Eds.) (2018) Catalog of Fishes: Genera, Species, References. Available from: http://researcharchive.calacademy.org/research/ichthyology/catalog/fishcatmain.as (accessed 5 May 2018)

Froese, R. \& Pauly, D. (Eds.) (2017) FishBase. Available from: http://www.fishbase.org/search.php (accessed 16 December 2017)

Fuentes, C.I., Acuña, E. \& Hernández, N.R. (2015) Biogeography of continental shelf and upper slope fishes off El Salvador, Central America. Journal of the Marine Biological Association of the United Kingdom, 95 (3), 611-622. https://doi.org/10.1017/S0025315414001167

GBIF (2016) Global Biodiversity Information Facility Home Page. Available from: http://gbif.org (accessed 3 January 2018)

González-Murcia, S., Chicas-Batres, F. \& Lovo, M.H. (2016) Community structure and height distribution of intertidal rockpool fish in Los Cóbanos, El Salvador. Pan American Journal of Aquatic Sciences, 11 (3), 227-242.

González-Murcia, S., Marín-Martínez, C.M. \& Ayala-Bocos, A. (2012) Intertidal rockpool icthyofauna of El Pital, La Libertad, El Salvador. Check List, 8 (6), 1216-1219. https://doi.org/10.15560/8.6.1216

González-Murcia, S. \& Marín-Martínez, C. (2011) First record of the clingfish Tomicodon zebra (Pisces: Gobiesocidae) from El Salvador waters. Marine Biodiversity Records, 4 (50), 1-2. https://doi.org/10.1017/S1755267211000443

Hamer, M. (2012) An assessment of zoological research collections in South Africa. South Africa. South African Journal of Science, 108 (11-12), 71-82.

https://doi.org/10.4102/sajs.v108i11/12.1090

Horta-Duarte, R. (2013) Between the National and the Universal: Natural History Networks in Latin America in the Nineteenth and Twentieth Centuries. Isis, 104 (4), 777-787. https://doi.org/10.1086/674944

Horton, T., Kroh, A., Ahyong, S., Bailly, N., Boury-Esnault, N., Brandão, S.N., Costello, M.J., Gofas, S., Hernández, F., Mees, 
J., Paulay, G., Poore, G.C.B., Rosenberg, G., Decock, W., Dekeyzer, S., Lanssens, T., Vandepitte, L., Vanhoorne, B., Verfaille, K., Adlard, R., Adriaens, P., Agatha, S., Ahn, K.J., Akkari, N., Álvarez, B., Anderson, G., Angel, M., Arango, C., Artois, T., Atkinson, S., Bank, R., Barber, A., Barbosa, J.P., Bartsch, I., Bellan-Santini, D., Bernot, J., Berta, A., Bieler, R., Blanco, S., Blasco-Costa, I., Blazewicz, M., Bock, P., Böttger-Schnack, R., Bouchet, P., Boxshall, G., Boyko, C.B., Bray, R., Bruce, N.L., Cairns, S., Campinas Bezerra, T.N., Cárdenas, P., Carstens, E., Chan, B.K., Chan, T.Y., Cheng, L., Churchill, M., Coleman, C.O., Collins, A.G., Corbari, L., Cordeiro, R., Cornils, A., Coste, M., Crandall, K.A., Cribb, T., Cutmore, S., Dahdouh-Guebas, F., Daly, M., Daneliya, M., Dauvin, J.C., Davie, P., De Broyer, C., De Grave, S., de Mazancourt, V., de Voogd, N., Decker, P., Defaye, D., d'Hondt, J.L., Dijkstra, H., Dohrmann, M., Dolan, J., Domning, D., Downey, R., Drapun, I., Ector, L., Eisendle-Flöckner, U., Eitel, M., Encarnação, S.C.d., Enghoff, H., Epler, J., EwersSaucedo, C., Faber, M., Feist, S., Figueroa, D., Finn, J., Fišer, C., Fonseca, G., Fordyce, E., Foster, W., Frank, J.H., Fransen, C., Furuya, H., Galea, H., García-Álvarez, O., Garic, R., Gasca, R., Gaviria-Melo, S., Gerken, S., Gheerardyn, H., Gibson, D., Gil, J., Gittenberger, A., Glasby, C., Glover, A., Gómez-Noguera, S.E., González-Solís, D., Gordon, D., Grabowski, M., Gravili, C., Guerra-García, J.M., Guidetti, R., Guilini, K., Guiry, M.D., Hadfield, K.A., Hajdu, E., Hallermann, J., Hayward, B., Hendrycks, E., Herrera Bachiller, A., Ho, J.S., Høeg, J., Hoeksema, B., Holovachov, O., Hooper, J., Houart, R., Hughes, L., Hyžný, M., Iniesta, L.F.M., Iseto, T., Ivanenko, S., Iwataki, M., Jarms, G., Jaume, D., Jazdzewski, K., Karanovic, I., Karthick, B., Kim, Y.H., King, R., Kirk, P.M., Klautau, M., Kociolek, J.P., Kolb, J., Kotov, A., Krapp-Schickel, T., Kremenetskaia, A., Kristensen, R., Kulikovskiy, M., Kullander, S., La Perna, R., Lambert, G., Lazarus, D., Le Coze, F., LeCroy, S., Leduc, D., Lefkowitz, E.J., Lemaitre, R., Liu, Y., Lörz, A.N., Lowry, J., Ludwig, T., Lundholm, N., Macpherson, E., Madin, L., Mah, C., Mamos, T., Manconi, R., Mapstone, G., Marek, P.E., Marshall, B., Marshall, D.J., Martin, P., McInnes, S., Meidla, T., Meland, K., Merrin, K., Mesibov, R., Messing, C., Miljutin, D., Mills, C., Moestrup, Ø., Mokievsky, V., Molodtsova, T., Monniot, F., Mooi, R., Morandini, A.C., Moreira da Rocha, R., Moretzsohn, F., Mortelmans, J., Mortimer, J., Musco, L., Neubauer, T.A., Neubert, E., Neuhaus, B., Ng, P., Nguyen, A.D., Nielsen, C., Nishikawa, T., Norenburg, J., O'Hara, T., Okahashi, H., Opresko, D., Osawa, M., Ota, Y., Patterson, D., Paxton, H., Perrier, V., Perrin, W., Petrescu, I., Picton, B., Pilger, J.F., Pisera, A., Polhemus, D., Potapova, M., Pugh, P., Read, G., Reimer, J.D., Reip, H., Reuscher, M., Reynolds, J.W., Rimet, F., Rios, P., Rius, M., Rützler, K., Rzhavsky, A., Sabbe, K., Saiz-Salinas, J., Sala, S., Santos, S., Sar, E., Sartori, A.F., Satoh, A., Schatz, H., Schierwater, B., SchmidtRhaesa, A., Schneider, S., Schönberg, C., Schuchert, P., Senna, A.R., Serejo, C., Shaik, S., Shamsi, S., Sharma, J., Shear, W.A., Shenkar, N., Shinn, A., Short, M., Sicinski, J., Siegel, V., Sierwald, P., Simmons, E., Sinniger, F., Sivell, D., Sket, B., Smit, H., Smit, N., Smol, N., Souza-Filho, J.F., Spelda, J., Sterrer, W., Stienen, E., Stoev, P., Stöhr, S., Strand, M., SuárezMorales, E., Summers, M., Suttle, C., Swalla, B.J., Taiti, S., Tanaka, M., Tandberg, A.H., Tang, D., Tasker, M., Taylor, J., Taylor, J., Tchesunov, A., ten Hove, H., ter Poorten, J.J., Thomas, J., Thuesen, E.V., Thurston, M., Thuy, B., Timi, J.T., Timm, T., Todaro, A., Turon, X., Tyler, S., Uetz, P., Utevsky, S., Vacelet, J., Vachard, D., Vader, W., Väinölä, R., Van de Vijver, B., van der Meij, S.E., van Haaren, T., van Soest, R., Van Syoc, R., Venekey, V., Vonk, R., Vos, C., Walker-Smith, G., Walter, T.C., Watling, L., Wayland, M., Wesener, T., Wetzel, C., Whipps, C., White, K., Williams, D., Williams, G., Wilson, R., Witkowski, A., Witkowski, J., Wyatt, N., Wylezich, C., Xu, K., Yasuhara, M., Zanol, J. \& Zeidler, W. (2018) World Register of Marine Species. Available from: http://www.marinespecies.org (accessed 20 January 2018)

Ko, H-L., Wang, Y.-T., Chiu, T.-S., Lee, M.-A., Leu, M.-Y., Chang, K.-Z., Chen, W.-Y. \& Shao, K.-T. (2013) Evaluating the Accuracy of Morphological Identification of Larval Fishes by Applying DNA Barcoding. PLOS ONE, 8 (1), e53451. https://doi.org/10.1371/journal.pone.0053451

Leis, J.M. (2015) Taxonomy and systematics of larval Indo-Pacific fishes: a review of progress since 1981. Ichthyological Research, 62, 9-28 https://doi.org/10.1007/s10228-014-0426-7.

MARN (2016) Ministerio de Medio Ambiente y Recursos Naturales. Inventario de peces El Salvador. Available from: http:// www.marn.gob.sv/descarga/inventario-de-peces-en-el-salvador/ (accessed 5 December 2017)

Marín-Martínez, C.M. (2011) Composición, diversidad y estructura del ictioplancton de la Bahía de La Unión, Golfo de Fonseca, El Salvador. Universidad de El Salvador, San Salvador, 85 pp.

Matamoros, W.A., Kreiser, B.R. \& Schaefer, J.F. (2012a) A delineation of Nuclear Middle America biogeographical provinces based on river basin faunistic similarities. Reviews in Fish Biology and Fisheries, 22, 351-365. https://doi.org/10.1007/s11160-011-9232-8

Matamoros, W.A., Schaefer, J.F., Hernández, C.L. \& Chakrabarty, P. (2012b) Profundulus kreiseri, a new species of Profundulidae (Teleostei, Cyprinodontiformes) from northwestern Honduras. ZooKeys, 227, 49-62. https://doi.org/10.3897/zookeys.227.3151

Matamoros, W.A., McMahan, C.D., Chakrabarty, P., Albert, J.S. \& Schaefer, J.F. (2015) Derivation of the freshwater fish fauna of Central America revisited: Myers's hypothesis in the twenty-first century. Cladistics, 31, 177-188. https://doi.org/10.1111/cla.12081

McMahan, C.D., Davis, M.P., Domínguez-Domínguez, O., García de León, F.J., Doadrio, I. \& Piller, K.R. (2013) From the mountains to the sea: phylogeography and cryptic diversity within the mountain mullet, Agonostomus monticola (Teleostei: Mugilidae). Journal of Biogeography, 40, 894-904. https://doi.org/10.1111/jbi.12036

McMahan, C.D., Matamoros, W.A., Álvarez Calderón, F.S., Henríquez, W.Y., Recinos H.M., Chakrabarty, P., Barraza, E. \& Herrera, N. (2013) Checklist of the Inland Fishes of El Salvador. Zootaxa, 3608 (6), 440-456. 
https://doi.org/10.11646/zootaxa.3608.6.2

McMahan, C.D., Matamoros, W.A., Barraza, E., Kutz, J. \& Chakrabarty, P. (2014) Taxonomic Status of the Lago Coatepeque Endemic Convict Cichlid Amatitlania coatepeque (Teleostei: Cichlidae). Copeia, 4, 633-638.

https://doi.org/10.1643/CI-13-153

Mendoza-Franco, E. F., Caspeta-Mandujano, J.M., Salgado-Maldonado, G. \& Matamoros, W.A. (2015) Two new species of Urocleidoides Mizelle et Price, 1964 (Monogenoidea) from the gill lamellae of profundulids and poeciliids from Central America and southern Mexico. Folia Parasitologica, 62, 59.

https://doi.org/10.14411/fp.2015.059

Miller, R.R., Minckley, W.L., Norris, S.M., Gach, M.H. \& Schmitter-Soto, J.J. (2009) Peces Dulceacuícolas de México. Comisión Nacional para el Conocimiento y Uso de la Biodiversidad, México, 180 pp.

Myers, G.S. (1949) Salt-tolerance of fresh-water fish groups in relation to zoogeographical problems. Bijdragen tot de Dierkunde, 28 (1949), 315-322.

Nelson, J.S., Grande, T.C. \& Wilson, M.V.H. (2016) Fishes of the World. $5^{\text {th }}$ Edition. John Wiley and Sons. Inc., Hoboken, New Jersey, $752 \mathrm{pp}$. https://doi.org/10.1002/9781119174844

Palacios, M., Voelker, G., Rodriguez, L.A., Mateos, M. \& Tobler, M. (2016) Phylogenetic analyses of the subgenus Mollienesia (Poecilia, Poeciliidae, Teleostei) reveal taxonomic inconsistencies, cryptic biodiversity, and spatio-temporal aspects of diversification in Middle America. Molecular Phylogenetics and Evolution, 103, 230-244. https://doi.org/10.1016/j.ympev.2016.07.025

Pinacho-Pinacho, C.D., García-Varela, M., Hernández-Orts, J. S., Mendoza-Palmero, C. A., Sereno-Uribe, A.L., MartínezRamírez, E., Andrade-Gómez, L., López-Jiménez, A., Hernández-Cruz, E. \& Pérez-Ponce de León, G. (2015) Checklist of the helminth parasites of the genus Profundulus Hubbs, 1924 (Cyprinodontiformes, Profundulidae), an endemic family of freshwater fishes in Middle-America. ZooKeys, 523, 1-30. https://doi.org/10.3897/zookeys.523.6088

Ponder, W.F., Carter, G.A., Flemons, P. \& Chapman, R.R. (2001) Evaluation of museum collection data for use in biodiversity assessment. Conservation Biology, 15, 648-657. https://doi.org/10.1046/j.1523-1739.2001.015003648.x

Robertson, D.R. \& Cramer, K.L. (2009) Shore fishes and biogeographic subdivisions of the Tropical Eastern Pacific. Marine Ecology Progress Series, 380, 1-17. https://doi.org/10.3354/meps07925

Robertson, D.R. \& Allen, G.R. (2015) Shorefishes of the Tropical Eastern Pacific. online information system. Version 2.0. Smithsonian Tropical Research Institute, Balboa. Available from: http://biogeodb.stri.si.edu/sftep/en/pages_(accessed 10 November 2017)

Robertson, D.R., Angulo, A., Baldwin, C.C., Pitassy, D., Driskell, A., Weigt, L. \& Navarro, I.J.F. (2017) Deep-water bony fishes collected by the B/O Miguel Oliver on the shelf edge of Pacific Central America: an annotated, illustrated and DNA-barcoded checklist. Zootaxa, 4348 (1), 1-125. https://doi.org/10.11646/zootaxa.4348.1.1

Rojas, J.R., Fuentes, C.I. \& Hernández, N.R. (2006) Echinorhinus cookei Pietschmann, 1928 (Chondrichthyes: Squaliformes, Echinorhinidae), primer registro en aguas de El Salvador, Pacífico Oriental Tropical. Revista de Biología Marina y Oceanografia, 41 (1), 117-119. https://doi.org/10.4067/S0718-19572006000100015

Sala, O.E., Stuart Chapin, F., Armesto, J.J., Berlow, E., Bloomfield, J., Dirzo, R., Huber-Sanwald, E., Huenneke, L.F., Jackson, R.B., Kinzig, A., Leemans, R., Lodge, D.M., Mooney, H.A., Oesterheld, M., Poff, N.L., Sykes, M.T., Walker, B.H., Walker, M. \& Wall, D.H. (2000) Global biodiversity scenarios for the year 2100. Science, 287, 1770-1774. https://doi.org/10.1126/science.287.5459.1770

Salgado-Maldonado, G., Matamoros, W.A., Caspeta-Mandujano, J.M., Martínez-Ramírez, E., Mendoza-Franco, E.F. \& Velázquez-Velázquez, E. (2014) Range extension of helminth parasites of Profundulus spp. (Teleostei: Profundulidae) from southern Mexico and Central America. Check List, 10, 1507-1513. https://doi.org/10.15560/10.6.1507

Shaffer, H.B., Fisher, R.N. \& Davidson, C. (1998) The role of natural history collections in documenting species declines. Trends in Ecology and Evolution, 13, 27-30. https://doi.org/10.1016/S0169-5347(97)01177-4

Suarez, A.V. \& Tsutsui, N.D. (2004) The value of Museum Collections for Research and Society. BioScience, 54 (1), 66-74.

Thiel, R., Eidus, I. \& Neumann, R. (2009) The Zoological Museum Hamburg (ZMH) fish collection as a global biodiversity archive for elasmobranchs and actinopterygians as well as other fish taxa. Journal of Applied Ichthyology, 25, 9-32. https://doi.org/10.1111/j.1439-0426.2009.01296.x

Vörösmarty, C.J., McIntyre, P.B., Gessner, M.O., Dudgeon, D., Prusevich, A., Green, P., Glidden, S., Bunn, S.E., Sullivan, C.A., Reidy Liermann, C. \& Davies, P.M. (2010) Global threats to human water security and river biodiversity. Nature, $467,555-561$. https://doi.org/10.1038/nature09440

Vörösmarty, C.J., Meybeck, M., Fekete, B., Sharma, K., Green, P. \& Syvitski, J.P.M. (2003) Anthropogenic sediment retention: 
Major global-scale impact from the population of registered impoundments. Global Planetary Change, 39, 169-190. https://doi.org/10.1016/S0921-8181(03)00023-7

Yesson, C., Brewer, P.W., Sutton, T., Caithness, N., Pahwa, J.S., Burgess, M., Gray, W.A., White R.J,. Jones, A.C, Bisby, F.A. \& Culham, A. (2007) How Global Is the Global Biodiversity Information Facility?. PLOS ONE, 11, e1124. https://doi.org/10.1371/journal.pone.0001124

Zapata, F.A. \& Robertson, D.R. (2007) How many species of shore fishes are there in the Tropical Eastern Pacific?. Journal of Biogeography, 34, 38-51.

https://doi.org/10.1111/j.1365-2699.2006.01586.x 